\title{
Şike Soruşturmasının Hisse Senedi Getirileri Üzerindeki Etkisi: Borsa İstanbul'da İşlem Gören Spor Kulüpleri Üzerine Bir Araştırma*
}

\section{The Impact of Match Fixing on the Share of Earning: An Application on Sports Clubs Traded in BIST}

\author{
Cemal Elitaş, Türkiye, cemalelitas@gmail.com \\ Mesut Doğan, Türkiye, mesutdogan@aku.edu.tr \\ Özkan Karahan, Türkiye, o.karahan034@ hotmail.com
}

\begin{abstract}
Öz: Son zamanlarda spor ekonomisi hızl bir șekilde büyümüștür. Spor ekonomisinin bu kadar hızlı bir șekilde büyümesi șike, teșvik primi ve diğer yasak fiil ve davranışları beraberinde getirmiştir. Bunun neticesinde dünyada ve ülkemizde birçok şike soruşturmast yaşanmış ve ülke futbol federasyonlarını bazı düzenlemeler yapmaya zorlamışstır. Bu araştırmanın amacı; Ulusal 100 (XU100) endeksi ile şike sorușturmasında adı geçen 3 büyük kulübün (Beşiktaş-BJK, Fenerbahçe-FB, Trabzonspor-TS) ve soruşturma kapsamı dışındaki Galatasaray'ın (GS) hisse senetleri üzerinde meydana getirdiği davranış değiş̧ikliklerini tespit etmektir. Araştırmada futbol kulüplerine ait günlük getiri verilerinin şike soruşturmasının başladığı tarih olan 03.07.2011 tarihi öncesi ve sonrası dönemler için ayrı ayrı analizler yapılmıştır. Yapılan analizler sonucunda, bu soruşturmanın tarafi olan ve Borsa İstanbul'da işlem gören spor kulüplerinin hisse senetlerinde dikkate değer önemli davranış değişiklikleri tespit edilmiştir.
\end{abstract}

Anahtar Kelimeler: Şike Soruşturması, Spor Kulüpleri, Hisse Senedi Getirileri

\begin{abstract}
Recently, sports economy has grown rapidly. So the rapid growth of the sport economy brought match fixing, use of incentive, premium and other prohibited acts and behaviors. As a result of this, a lot of match-fixing investigation was experienced in the world and in our country, the country's football federation was forced to make some arrangements. The purpose of this study is to determine the behavior changes on the stocks of three biggest football clubs (Beşiktaş-BJK, Fenerbahçe-FB, Trabzonspor-TS), which are listed in the National 100 Index and were mentioned in the match-fixing investigation, and to determine behavioral changes on the stocks of Galatasaray, which is out of the investigation. In this study, daily returns data of the football clubs were analyzed separately for the pre and post periods of match-fixing investigation in 03/07/2011.At the end of the analysis, this study demonstrates that important behavioral changes weren't observed in the stocks of sports clubs listed in Istanbul Stock Exchange and involved in the match fixing investigation.
\end{abstract}

Keywords: Match Fixing Investigation, Sports Clups, Share of Earnings

\section{Giriş}

Spor ekonomisi içerisinde en büyük paya sahip olan futbol endüstrisinin; Avrupa'da 14,6 milyar Euro y1llık cirosu bulunmaktadır. Türkiye'de ise futbol endüstrisi son yıllarda ivme kazanmış ve 800 milyon Euro gibi önemli bir büyüklüğe ulaşarak Avrupa'da 6. sıraya ulaşmıştır. Spor ekonomisinin bu kadar hızlı bir şekilde büyümesi şike, teşvik primi ve diğer yasak fiil ve davranışları beraberinde getirmiştir. Bunun neticesinde dünyada ve ülkemizde birçok şike soruşturması yaşanmış, bu durum ülke futbol federasyonlarını bazı düzenlemeler yapmaya zorlamıştır.

Spor Toto Süper Lig'de 2010-2011 sezonunun sonunda Fenerbahçe şampiyon olmuştur. Buna karşın 3 Temmuz 2011 tarihinde; 2010-2011 sezonunda TFF 1. Lig ve Spor Toto Süper Lig'in bazı müsabakalarında şike yapıldığı ve teşvik primi verildiği iddiası üzerine soruşturma başlatılmıştır. Bu soruşturma ile spor kulüplerinin marka ve piyasa değerleri önemli bir şekilde etkilenmiştir. Özellikle bazı spor kulüplerine verilen Avrupa Lig'lerine katılmaktan men cezası, kulüplerin ciddi anlamda gelir kaybına uğramasına neden olmuştur.

Halka açık olan spor kulüplerinde, özellikle taraftarların tuttukları takımın hisselerini almaları çok doğaldır. Şike soruşturması kapsamında 3 Temmuz 2011'de Türkiye'de büyük kulüplerin ve bazı birinci lig kulüplerinin yetkilileri ile birlikte çok sayıda ismin tutuklanması ve gözaltına alınması borsada işlem gören kulüplerin hisse senetlerinde büyük düşüşler meydana getirmiştir. Nitekim tuttukları takımın hisselerini alan küçük yatırımcılar hisse senetlerindeki büyük düşüşler sonucunda büyük zararlara uğramışlardır. Bu nedenle bu şirketlerin hisse senetlerinin değer kaybetmesi hem spor kulübünü hem de küçük yatırımcıyı etkilemiştir (Donay, 2011: 115).

$\mathrm{Bu}$ araştırmanın amacı, şike soruşturmasının; piyasanın genel performansı hakkında bilgi veren Ulusal 100 (XU100) endeksi ile şike soruşturmasında adı geçen 3 büyük kulübün (Beşiktaş-BJK, Fenerbahçe-FB, Trabzonspor-TS) ve soruşturma kapsamı dışındaki Galatasaray’ın (GS) hisse senetleri üzerinde meydana getirdiği davranış değişikliklerini tespit etmektir. Başka bir ifade ile bu araştırmada şike iddiası ile ilgili haberlerin getiri değişkenliğinde yarattığı olası etkiler tespit edilecektir. Araştırmada futbol kulüplerine ait günlük getiri verileri üzerinde şike soruşturmasının başladığı tarih olan 03.07.2011 tarihi öncesi ve sonrası dönemler (soruşturma öncesi ve sonrası) için ayrı ayrı analizler yapılmıştır. Böylelikle söz konusu iki dönem arasındaki hisse senedi getiri davranış farklılıkları ve şike soruşturmasından spor

\footnotetext{
* Bu araştırma 21-24 Ekim 2015 tarihleri arasında Hitit Üniversitesi tarafından düzenlenen 19. Finans Sempozyumu'nda bildiri olarak sunulmuştur.
} 
kulüplerinin ne derece etkilendikleri ortaya konacaktır. Bu amaçlarla bu araştırmada bazı sorulara cevap aranmaktadır. Spor kulüplerinin getiri serilerinin şike soruşturması sonrasında piyasa portföyünden etkilenme düzeylerinde nasıl bir değişim meydana gelmiştir? Şike soruşturması spor kulüp getirilerine ilişkin riski ne yönde ve ne derece etkilemiştir?

Çalışmada her bir spor kulübünün soruşturma öncesine ve sonrasına ait 566 gözlem değeri elde edilmiştir. Araştırmada incelenen değişkenler arasındaki nedensellik ilişsilerinin tespit edilmesi için Etki-Tepki Fonksiyonları (Impulse-Response Functions), Varyans Ayrıştırması (Variance Decomposition) ve GRANGER Nedensellik (Granger Causalty) testlerinden faydalanılmıştır. Ayrıca Ulusal 100 endeks getirileri ile 4 büyük kulübün getirilerindeki oynaklığın modellenmesinde Eşik ARCH (TARCH), Üssel GARCH (EGARCH) ve Üstel ARCH (PARCH) yöntemleri kullanılmıştır.

Konuya ilişkin literatür taramasında şike soruşturmasının ve şike haberlerinin hisse senedi getirileri üzerindeki etkisini inceleyen bir araştırmaya rastlanmıştır. Bu çalışmada Gökten ve Karatepe (2015) şike haberlerinin yayınlanması süreçlerinde hisse senedi fiyatlarında anormal getiriler olduğunu tespit etmişlerdir.

Araştırma beş bölümden oluşmaktadır. Girişten sonra etik, şike, etik ahlak ilişkisi, spor etiği gibi konulardan bahsedilmiştir. Üçüncü bölümde çalışmanın amacı, evren ve örneklemi ve yöntemi açıklanmıştır. Dördüncü bölümde ampirik bulgulara yer verilmiştir. Son bölümde ise çalışmanın genel bir değerlendirilmesi yapılmıştır.

\section{Etik}

Etimolojik kökeni Yunanca "ethos" a dayanan ve töre bilimi olarak da tanımlanan etik, insanın eylemlerini ahlaki bakımdan değerli veya değersiz kılanın ne olduğunu araştıran felsefi bir disiplin olarak kabul edilmektedir (Kısakürek ve Alpan, 2010: 214). Etik içinde hem bireysel hem de toplumsal sorular felsefenin ilk günlerinden itibaren yer almaktadır (Kaypak, 2010: 90). Dolayısıyla toplumların da bireylerden oluştuğunu göz önünde bulundurursak insanın olduğu her yerde etikten bahsetmek mümkündür. Ve bu konuda şu şekilde bir sınıflandırma yapılabilir (Yılmaz, 2009: 134):

- Bireysel Etik

- Toplumsal Etik

- Mesleki Etik

Bireysel etik, insanın kendi vicdanında oluşturduğu etik standartlarla ilgili iken (Akyıldız, 2007: 24), toplumsal etik; insanların toplum içinde yaşamaları sonucu oluşturdukları kültür, değer ve normlarla ilişkilidir. Toplumda yer alan bireylerin toplum içinde nasıl davranmaları gerektiğine yöneliktir. Örneğin; çevre etiği, kamusal alanda etik vs. (Yılmaz, 2009: 134). Mesleki etik ise, belirli bir meslek grubunun, mesleğe ilişkin olarak oluşturduğu ve koruduğu, meslek üyelerini belli bir şekilde davranmaya zorlayan, kişisel eğilimleri sınırlayan, yetersiz ve ilkesiz üyeleri meslekten dışlayan, meslek içi rekabeti düzenleyen ve hizmet ideallerini korumayı amaçlayan mesleki ilkeler bütünü olarak tanımlanabilir. Örneğin; tıp etiğii, muhasebe etiği, spor etiği vs. (Aydın, 2012: 4).

\subsection{Etik-Ahlak İlişkisi}

Etimolojik olarak bakıldığında etik ve ahlak kavramları aynı anlamlara (töre, gelenek, alışkanlık vb.) geliyor gözükse de, ahlakın olgusal ve tarihsel olarak yaşanan bir şey olmasına karşılık, etik, bu olgunun kendisine yönelik araştırmasıdır (Tokgöz, 2013: 5). Ahlak ile etik arasındaki ilişkiyi açıklamak ve anlatmak bakımından tiyatro eleştirmenleri ile tiyatrocular, futbol eleştirmenleri ya da hakemler ile futbolcular arasındaki ilişkiler örnek verilebilir. Bu ikili ilişkilerde ilkler konulara eleştirel bir yaklaşımla değerlendirme yaparlarken, ikinciler ise bizzat uygulayıcılar olarak işlerini yerine getirmektedirler. Eleştirmenler uygulayıcıların yerlerine geçmeden değerlendirme yapmaktadırlar. Buna benzer şekilde etikle uğraşanlarda ahlak konusuna belli bir mesafeden yaklaşarak değerlendirmede bulunmaktadırlar. Etikle uğraşanlar sadece bir bilim adamı olarak eleştirel bir yaklaşımla ahlaki olanı ortaya koymakta ve yansıtmakta, ancak ahlaki eylemlerde bulunmamaktadırlar. Bir başka ifadeyle etik, ahlaki pratiğin kuramı olarak bizzat ahlak pratiği değildir (Mahmutoğlu, 2009: 231).

\subsection{Spor Etiği}

Son zamanlarda dünyada sporun amacından saptırılarak bir takım çıkarlar için araç haline getirilmesi ve ahlaki değerlerle maddi değerlerin yer değiştirmesi, spor alanında etiğe duyulan ihtiyacı daha iyi ortaya koymaktadır. Sporun taraflarının (teknik direktör, sporcu, hakem, yönetici, taraftar, medya) görevlerini ifa ederken bir takım etik ilkeleri göz ardı etmeleri, spor adına etik dışı gelişmelerin yaşanmasına yol açmaktadır (Tuncel ve Büyüköztürk, 2009: 160).

Spor etiği kavramı genel anlamda, sporun gelişmesinde rol oynayan sporun taraflarının görev ve sorumluluklarını dürüstlük, adalet, açıklık, tarafsızlık ve saygı gibi evrensel değerler doğrultusunda yerine getirmeleri ve çalışmalarını etik ilkelere bağlamalarını kapsamaktadır. Spor etiğinin amacı, bireylere spor alanında kabul görmüş evrensel etik ilkelerinin benimsetilerek sporun yapıldığı ortamlarda davranış boyutunda sergilenmesini sağlamaktır (Tuncel ve Büyüköztürk, 2009: 160).

Sporda etik dışı davranışların sebebi olarak spor ekonomisinin gün geçtikçe büyümesi ve sporun taraflarının daha fazla kazanma isteği gösterilebilir. Çünkü spor alanlarında "kazanmak için her yol mubahtır" felsefesi sporun tarafları tarafından sergilenen davranışların etik açıdan kontrolünü ortadan kaldırmaktadır. 
Son yıllarda sıkça gündeme gelen sporda şiddet, saldırganlık, şike ve teşvik primi, bahis oyunu skandalları gibi konular göstermektedir ki, spor etiğinin daha iyi anlaşılmasına ve anlatılmasına ihtiyaç vardır. İster amatörlükte ve isterse profesyonellikte olsun başarı ihtiyacı, Fair Play kurallarına uygun davranmayı gerektirir. Fair Play, zor şartlar altında dahi kurallara uyma ve dürüst davranma ile kendini gösterir. Günümüzde spor faaliyetlerinde ne yazık ki Fair Play kurallarına uygun olan az sayıda davranış, uygun olmayan ise çok sayıda davranış gözlemlenmektedir (Şenol, 2013: 714).

\section{3. Şike}

Büyük bir ekonomik sektör haline gelen sporda, gelir pastasından farklı şekillerde pay almak isteyen sporcular, yöneticiler vs. değişik yöntemler keşfederek bir adım öne geçmeyi hedeflemişlerdir. Eskiden sadece amatör duygularla spor yapılmasına ve başarılı olarak manevi açıdan tatmin elde edilmesine karşın, günümüzde sporun kazanç elde etme amacı güdülen bir uğraş haline dönüşmesiyle spor karşılaşmalarının sonucuna bağlı maddi kazançlar elde etme isteği de önem kazanmıştır. Sporu normal yollarla icra edip maddi kazanç elde etmek isteyenlerin yanında, etik dışı yollar vasıtasıyla gelir elde etme yolunu seçen kişiler de bulunmaktadır (Seydi, 2013).

6222 sayılı Kanuna göre ise şike, "Belirli bir spor müsabakasının sonucunu etkilemek amacıyla bir başkasına kazanç veya sair menfaat temin etmek” şeklinde tanımlanmıştır. Türkiye Futbol Federasyonu (TFF)'nin özerkliğini kazandığg 1992 yılında, 01.11.1992 tarih ve 21392 sayılı resmi gazetede yayınlanarak yürürlüğe giren ilk Futbol Disiplin Talimatı'nın “Hileli ve Danışıklı Futbol Müsabakası” başlıklı 38. Maddesi’nde “şike yapmak/yaptırmak” eylemi “Hileli ve danışıklı futbol müsabakası yapan, yaptıran kişiler ve aracıları en az bir yıl müsabakadan men cezası veya o kadar süre ile hak mahrumiyeti ve teşekküller Futbol Federasyonunca küme düşürme cezası ile cezalandırılır” şeklinde ifade edilmiştir (Tuzcuoğlu, 2011: 109).

Son 3 Temmuz 2011 tarihinde birçok yönetici, futbolcu, menajer ve aracının gözaltına alınması ile başlayan dava sürecinde karşımıza çıkan bahis şikesi, hatır şikesi ve transfer şikesi kavramları sıkça duyulmaya başlanmıştır. Bahis şikesi, maçın sonucu ne olursa olsun suçun failinin asıl amaçladığı şeyin bahis oyunu sonucunda kazanacağı menfaat olmasıdır. Bu şike türü sadece bahis oyunlarının oynanabildiği spor müsabakalarında yapılır (Yılmaz, 2012: 325-326). Hatır şikesi, taraflar arasında daha önceye dayanan hatır ilişkisinin ve manevi bağlılığın kullanılması sonucu spor müsabakasının sonucuna etki edilmeye çalışılmasıdır (Şen ve Özdemir, 2012: 6). Transfer şikesi ise, bir sporcunun bir kulübe transfer vaadiyle o kulübün maçında oynamaması, kötü oynaması ya da bilerek kart görerek oyun dışında kalması, rakip takımın maçında ise iyi oynamasının sağlanması ve transfer döneminde transfer edilmesi şeklinde tanımlanabilir (Y1lmaz, 2012: 325).

Şike, teşvik primi şeklinde de karşımıza çıkmaktadır. Suçun, bir müsabakada bir takımın başarılı olmasını sağlamak amacıyla teşvik primi verilmesi veya vaat edilmesi suretiyle işlenmesi halinde, teşvik primi verme suçu oluşacaktır (6222 sayılı Kanun md. 11/5). Teşvik primi, başka bir takımın oyuncularına oynayacakları müsabakayla ilgili, üçüncü takımlar yararına bir performans ortaya koymaları ile oynayacakları maçı kazanmaya yönelik motive etme çalışmasına karşı verilen kayıt dışı para veya menfaat olarak tanımlanabilir (Özen ve Yılmaz, 2012: 30).

Esas itibariyle, şike yapılması ve teşvik primi verilmesi/alınması fiilleri birbirinden farklıdır. Şike suçunda, bir müsabakada olması gereken yarışma taraflardan biri aleyhine azaltılmakta iken teşvik primi verme suçunda müsabakadaki çekişme artırılmaktadır (Şen ve Özdemir, 2012: 10).

Şike suç olmakla birlikte birtakım olumsuz sonuçları da beraberinde getirmektedir. Sağladığı dışsallıklar nedeniyle kendisi dışında birçok sektöre de ilave katma değerler yaratan futbolun yaşadığı gelir kayıpları şike ekonomisinin gelirlerini oluşturmaktadır (Akşar, 2011). Şike ekonomisi ile futbol ekonomisi arasında doğru orantılı bir gelişim söz konusudur. Futbolda parasallaşmanın boyutu artıkça, şike ekonomisinin boyutu da artmaktadır. Futbol sektöründe ticari gelirlerin artması ile birlikte şikenin temel dinamiğini oluşturan faktörlerin futbola olan ilgisi artmaya başlamaktadır. Ancak bu ikili arasında rekabet gücü bakımdan ters yönlü bir ilişki bulunmaktadır. Şike ekonomisi geliştikçe futbolun izlenirliliği başka bir ifade ile reytingi düşmeye başlıyor. Taraftarlar maçlara ilgi göstermiyor. Sponsorlar kulüplerden desteklerini çekiyor. Bütün bunlar futbolun rekabet gücünün düşmesine ve uzun vadede ölümü anlamına geliyor. Şike olaylarının olduğu ligler izlenmiyor. Bu yüzden de futbol ekonomisinin gelirleri düşmeye başlıyor. Bugün Malezya, Singapur ve Çin'de futbola olan ilgi fazla olmasına karşın şike olaylarının yaygınlığı, yerel ligler yerine uluslararası liglerin daha fazla izlenmesine yol açıyor (Akşar, 2011). 


\section{Metodoloji}

Metodoloji bölümünde araştırmanın amacı, evren ve örneklemi, yöntemi ve araştırmada kullanılan değişkenler anlatılmıştır.

\subsection{Araştırmanın Amacı}

Bu araştırmanın amacı; Ulusal 100 (XU100) endeksi ile şike soruşturmasında adı geçen 3 büyük kulübün (Beşiktaş-BJK, Fenerbahçe-FB, Trabzonspor-TS) ve soruşturma kapsamı dışındaki Galatasaray’ın (GS) hisse senetleri üzerinde meydana getirdiği davranış değişikliklerini tespit etmektir. Başka bir ifade ile bu araştırmada şike iddiası ile ilgili haberlerin getiri değişkenliğinde yarattığı olası etkiler tespit edilecektir. Araştırmada futbol kulüplerine ait günlük getiri verilerinin şike soruşturmasının başladığı tarih olan 03.07.2011 tarihi öncesi ve sonrası dönemler (soruşturma öncesi ve sonrası) için ayrı ayrı analizler yapılmıştır. Böylelikle söz konusu iki dönem arasındaki hisse senedi getiri davranış farklılıkları ve şike soruşturmasından spor kulüplerinin ne derece etkilendikleri ortaya konacaktır.

\subsection{Araştırmanın Evren ve Örneklemi}

Bu araştırmada şike soruşturmasında adı geçen 3 büyük kulübün BJK, FB, TS ve soruşturma kapsamı dışındaki GS spor kulübü analizlere dâhil edilmiştir. Şike soruşturmasında adı geçmesine rağmen BJK, FB ve TS dışındaki kulüplerin (Bucaspor, Bursaspor, Eskişehirspor, Gençlerbirliği, İstanbul Büyükşehir Belediyespor, Kardemir Karabükspor, Kasımpaşa, Kayserispor, Konyaspor, Manisaspor, MKE Ankaragücü, Sivasspor) hisse senetleri Borsa İstanbul'da işlem görmediği için analizlere dâhil edilememiştir.

\subsection{Araşstırmada Kullanılan Değişkenler}

Çalışmada her bir spor kulübünün soruşturma öncesine ve sonrasına ait 566 gözlem değeri elde edilmiştir. Yani 3 Temmuz 2011 tarihindeki şike soruşturması öncesine ve sonrasına ait borsanın açık olduğu 566 gözlem değeri mevcuttur. Sonuçlar karşılaştırılabilmesi açısından gözlem sayıları eşit olarak alınmıştır. Toplamda 1132 gözlem değeri elde edilmiştir. Çalışmada Ulusal 100 endeksine ilişkin getiri verileri ve dört büyük kulübün gün sonu kapanış değerlerinden yararlanılmıştır. Çalışmada kullanılan tüm veriler Borsa İstanbul'dan elden edilmiştir. Analizlerde kullanılan tüm değişkenler Tablo 1'de gösterilmiştir.

Tablo 1. Analizlerde Kullanılan Değişkenler

\begin{tabular}{|l|l|}
\hline DEĞIŞKENLER & \multicolumn{1}{c|}{ AÇIKLAMA } \\
\hline GETIRIFB & Fenerbahçe Sportif Hisse Senedi Günlük Getiri Oranları (Kapanış Fiyatları Baz Alınarak) \\
\hline GETIRIBJK & Beşiktaş Sportif Hisse Senedi Günlük Getiri Oranları (Kapanış Fiyatları Baz Alınarak) \\
\hline GETIRIGS & Galatasaray Sportif Hisse Senedi Günlük Getiri Oranları (Kapanış Fiyatları Baz Alınarak) \\
\hline GETIRITS & Trabzonspor Sportif Hisse Senedi Günlük Getiri Oranları (Kapanış Fiyatları Baz Alınarak) \\
\hline XU100GETIRI & IMKB 100 Endeksi Günlük Getiri Oranları (Kapanış Fiyatları Baz Alınarak) \\
\hline
\end{tabular}

\subsection{Araştırmanın Yöntemi}

$\mathrm{Bu}$ araştırmada getiri serilerine ilişkin oynaklık tahminleri için TARCH, EGARCH ve PARCH modellerinden yararlanılmıştır. Ayrıca, analizlerde yanıltıcı sonuçlarla karşılaşmamak için otoregresif modellerin geçerliliği ve güvenirliliği açısından oldukça önemli olan durağanlık testleri yapılmıştır. Zaman serileri arasında uzun dönemli bütünleşik ilişkilerin var olup olmadığıyla ilgili sayısal tespitlerde bulunabilmek için eşbütünleşme testlerinden faydalanılmıştır. Ayrıca değişkenlerin kendi değerlerinden etkilenip etkilenmediklerinin tespit etmek amacıyla ARCHLM testi ve CORRELOGRAM yöntemleri kullanılmıştır. Daha sonra, çapraz korelasyon analizi ve Granger Nedensellik Testi yardımıyla modellerde kapsanan değişkenler arasındaki öncül-ardıl ilişkilerin varlığı araştırılmıştır. İlişkilerinin yönünün tespitinde ise Varyans Ayrıştırması ve Etki-Tepki yöntemlerine yer verilmiştir. Getiri oynaklığının tahmini amaciyla üretilen TARCH, EGARCH ve PARCH modelleri arasında en iyi olduğu tespit edilen model önerilerinin tahmin hataları üzerinde otokorelasyon testleri gerçekleştirilerek, otokorelasyonun var olmadığına ilişkin destekleyici bulgular elde edilmeye çalışılmıştır. Yapılan tüm analizlerde ve oluşturulan ekonometrik modellerde EViews 7 paket programından yararlanılmıştır. 


\section{Ampirik Bulgular}

Tablo 2'de 3 Temmuz 2011 öncesine ait spor kulüplerinin hisse senedi getirileri ile ulusal 100 endeksi arasındaki ilişkiyi gösteren korelasyon analizi sonuçları yer almaktadır.

Tablo 2. 3 Temmuz 2011 Öncesine Ait Korelasyon Analizi

\begin{tabular}{|c|c|c|c|c|c|}
\hline $\begin{array}{c}\text { KORELASYON } \\
\text { MATRİII }\end{array}$ & 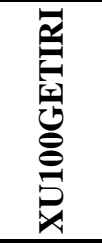 & 米 & 穿 & 茪 & 岂 \\
\hline XU100GETIRI & 1,000 & 0,215 & 0,178 & 0,174 & 0,188 \\
\hline
\end{tabular}

Korelasyon sonuçları incelendiğinde BJK, FB, GS ve TS getiri serileri ile endeks getiri serisi arasında pozitif bir ilişkinin olduğu görülmektedir.

Tablo 3. 3 Temmuz 2011 Sonrasina Ait Korelasyon Analizi

\begin{tabular}{|c|c|c|c|c|c|}
\hline $\begin{array}{c}\text { KORELASYON } \\
\text { MATRISI }\end{array}$ & 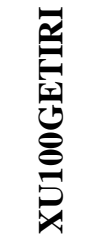 & 光 & 量 & 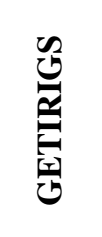 & 葛 \\
\hline XU100GETIRI & 1,000 & 0,181 & 0,259 & 0,219 & 0,315 \\
\hline
\end{tabular}

Tablo 3'te 3 Temmuz 2011 sonrasına ait spor kulüplerinin hisse senedi getirileri ile ulusal 100 endeksi arasındaki ilişkiyi gösteren korelasyon analizi sonuçları yer almaktadır. Tablo 3 'te BJK, FB, GS ve TS getiri serileri ile XU100 endeks getirisi arasında pozitif bir ilişki mevcuttur. Ancak şike soruşturma öncesi dönemle karşılaştırıldığında, FB, GS ve TS getiri serilerinin XU100 endeks getirisi ile etkileşiminin arttığı görülmektedir. Şike soruşturması sonrası dönem için XU100 endeksi ile etkileşimi en fazla TS getiri serileridir. BJK getiri serisinin ise, FB, GS ve TS getiri serilerinin aksine XU100 endeks getirisiyle etkileşimi azalmaktadır.

Tablo 4. Durağanlık Testi Sonuçları

\begin{tabular}{|c|c|c|c|c|c|c|}
\hline \multirow{2}{*}{ DEĞIŞKEN } & \multirow{2}{*}{ VERI } & \multirow{2}{*}{ DÜZEY } & \multicolumn{2}{|c|}{$\begin{array}{c}\text { 3 Temmuz Öncesi } \\
\text { Veri Seti }\end{array}$} & \multicolumn{2}{|c|}{$\begin{array}{c}\text { Temmuz Sonrası } \\
\text { Veri Seti }\end{array}$} \\
\cline { 4 - 7 } & & & ADF & Anlamlılık & ADF & Anlamlılık \\
\hline \multirow{2}{*}{ BJK } & GETİRİ & SEVIYY & $-18,4195$ & 0,0000 & $-23,2706$ & 0,0000 \\
\hline FB & GETİRİ & SEVIYYE & $-20,5516$ & 0,0000 & $-21,9811$ & 0,0000 \\
\hline GS & GETİRİ & SEVIYYE & $-18,6101$ & 0,0000 & $-21,9309$ & 0,0000 \\
\hline TS & GETİRİ & SEVIYYE & $-20,9624$ & 0,0000 & $-20,3069$ & 0,0000 \\
\cline { 4 - 7 } \\
\cline { 4 - 7 } & GETİRİ & SEVIYYE & $-22,8430$ & 0,0000 & $-24,6099$ & 0,0000 \\
\hline
\end{tabular}

Tablo 4'te serilerin durağan olup olmadığı test etmek için Artırılmış Dickey-Fuller (ADF) yöntemi kullanılmıştır. Değişkenler arasında istatistiksel olarak anlamlı ilişkiler elde edebilmek serilerin durağan olması gerekir. Tablo 4 incelendiğinde her iki dönem için de serilerin durağan olduğunu görülmektedir. Bu yüzden, modellerde tüm değişkenler için seviye değerler temel alınmıştır. 
Tablo5. Uygun Gecikme Uzunlukları

\begin{tabular}{|l|c|c|}
\hline \multirow{2}{*}{ DEĞIŞKENLER } & \multicolumn{2}{|c|}{ UYGUN GECIKME UZUNLUĞU (gün) } \\
\cline { 2 - 3 } & $\begin{array}{c}\text { 3 TEMMUZ } \\
\text { ÖNCESI }\end{array}$ & $\begin{array}{c}\text { 3 TEMMUZ } \\
\text { SONRASI }\end{array}$ \\
\hline GETIRIBJK - XU100GETIRI & 2 & 1 \\
\hline GETIRIFB - XU100GETIRI & 2 & 4 \\
\hline GETIRIGS - XU100GETIRI & 1 & 1 \\
\hline GETIRITS - XU100GETIRI & 1 & 6 \\
\hline
\end{tabular}

Tablo 5 'te VAR, varyans ayrıştırması, etki-tepki ve eşbütünleşme analizleri öncesinde uygun gecikme uzunluklarının tespiti amacıyla gerçekleştirdiğimiz testlerin çıktıları yer almaktadır. Analizde LR test istatistiği (LR), Nihai Tahmin Hatası (FPE), Akaike Bilgi Kriteri (AIC), Schwarz Bilgi Kriteri (SC) ve Hannan-Quinn Bilgi Kriteri (HQ) ölçütlerinin seçimleri doğrultusunda tabloda yer alan uygun gecikme sürelerine ulaşılmıştır.

Tablo 6. 3 Temmuz 2011 Öncesi GETIRIBJK Varyans Ayrıştırması ve Etki-Tepki Analizi Sonuçları

\begin{tabular}{|c|c|c|c|c|c|}
\hline \multicolumn{4}{|c|}{ Varyans Ayriștırması GETIRIBJK } & \multicolumn{2}{c|}{ Etki-Tepki GETIRIBJK } \\
\hline Dönem & Standart Hata & GETIRIBJK & XU100GETIRI & GETIRIBJK & XU100GETIRI \\
\hline $\mathbf{1}$ & 0.046394 & 100.0000 & 0.000000 & 0.046394 & 0.000000 \\
\hline $\mathbf{2}$ & 0.047603 & 99.99076 & 0.009245 & 0.010651 & $-0,000458$ \\
\hline $\mathbf{3}$ & 0.048007 & 99.73871 & 0.261294 & 0.005731 & $-0,002411$ \\
\hline $\mathbf{4}$ & 0.048058 & 99.72150 & 0.278504 & 0.002107 & $-0,00064$ \\
\hline $\mathbf{5}$ & 0.048063 & 99.71903 & 0.280965 & 0.000698 & $-0,000242$ \\
\hline $\mathbf{6}$ & 0.048064 & 99.71864 & 0.281360 & 0.000261 & $-9,66 \mathrm{E}-05$ \\
\hline $\mathbf{7}$ & 0.048064 & 99.71860 & 0.281402 & $9.12 \mathrm{E}-05$ & $-3,18 \mathrm{E}-05$ \\
\hline $\mathbf{8}$ & 0.048064 & 99.71859 & 0.281408 & $3.20 \mathrm{E}-05$ & $-1,15 \mathrm{E}-05$ \\
\hline $\mathbf{9}$ & 0.048064 & 99.71859 & 0.281409 & $1.14 \mathrm{E}-05$ & $-4,09 \mathrm{E}-06$ \\
\hline $\mathbf{1 0}$ & 0.048064 & 99.71859 & 0.281409 & $4.00 \mathrm{E}-06$ & $-1,43 \mathrm{E}-06$ \\
\hline
\end{tabular}

Tablo 6'da şike soruşturması öncesi dönem için BJK getiri serisinin varyans ayrıştırması ve etki-tepki analizi sonuçları gösterilmiştir. BJK getiri serisinin oynaklığında meydana gelen değişimlerin en az \%99,71'i kendi gecikmeli değişimlerinden kaynaklanmaktadır. XU100 endeksinin etkisi ise en fazla \%0,28 seviyesine ulaşmıştır. Diğer yandan, BJK getiri serisinin en fazla kendi değerlerinde oluşan gecikmeli şoklardan aynı yönde etkilendiği ve bu etkinin ilk gün en yüksek değerine ulaştıktan sonra ikinci gün neredeyse ortadan kalktığı söylenebilir. Yine BJK getiri serisinin XU100 getiri endeksinde meydana gelen şoklardan aynı yönde etkilendiği ve bu etkinin üçüncü günde en yüksek değerine ulaştıktan sonra 4. günde neredeyse ortadan kalktığı görülmektedir.

Tablo 7. 3 Temmuz 2011 Sonrası GETIRIBJK Varyans Ayrıştırması ve Etki-Tepki Analizi Sonuçları

\begin{tabular}{|c|c|c|c|c|c|}
\hline \multicolumn{5}{|c|}{ Varyans Ayrıstırması GETIRIBJK } & \multicolumn{2}{c|}{ Etki-Tepki GETIRIBJK } \\
\hline Dönem & Standart Hata & GETIRIBJK & XU100GETIRI & GETIRIBJK & XU100GETIRI \\
\hline $\mathbf{1}$ & 0.051699 & 100.0000 & 0.000000 & 0.051699 & 0.000000 \\
\hline $\mathbf{2}$ & 0.051725 & 99.90710 & 0.092901 & 0.000463 & 0.001577 \\
\hline $\mathbf{3}$ & 0.051725 & 99.90701 & 0.092985 & $-4,87 \mathrm{E}-05$ & $-4,74 \mathrm{E}-05$ \\
\hline $\mathbf{4}$ & 0.051725 & 99.90701 & 0.092985 & $1.15 \mathrm{E}-06$ & $3.66 \mathrm{E}-07$ \\
\hline $\mathbf{5}$ & 0.051725 & 99.90701 & 0.092985 & $-1,94 \mathrm{E}-09$ & $2.09 \mathrm{E}-08$ \\
\hline $\mathbf{6}$ & 0.051725 & 99.90701 & 0.092985 & $-7,18 \mathrm{E}-10$ & $-8,74 \mathrm{E}-10$ \\
\hline $\mathbf{7}$ & 0.051725 & 99.90701 & 0.092985 & $2.29 \mathrm{E}-11$ & $1.23 \mathrm{E}-11$ \\
\hline
\end{tabular}




\begin{tabular}{|c|c|c|c|c|c|}
$\mathbf{8}$ & 0.051725 & 99.90701 & 0.092985 & $-2,06 \mathrm{E}-13$ & $2.19 \mathrm{E}-13$ \\
\hline $\mathbf{9}$ & 0.051725 & 99.90701 & 0.092985 & $-9,20 \mathrm{E}-15$ & $-1,48 \mathrm{E}-14$ \\
\hline $\mathbf{1 0}$ & 0.051725 & 99.90701 & 0.092985 & $4.15 \mathrm{E}-16$ & $2.99 \mathrm{E}-16$ \\
\hline
\end{tabular}

Tablo 7'de şike soruşturması sonrası dönem için BJK getiri serisinin varyans ayrıştırması ve etki-tepki analizi sonuçları gösterilmiştir. BJK getiri serisinin daha çok kendi değerlerindeki değişimlerden etkilendiği (en az \%99,90), buna karşın XU100 getiri değişimlerinin neden olduğu etkinin en fazla \%0,09 düzeyinde kaldığ görülmektedir. Şike soruşturması sonrası dönem için XU100 endeksindeki değişimlerden etkilenme yüzdesi azalmış, buna karşın kendi değerlerindeki değişimlerden etkilenme yüzdesi artmıştır. Diğer yandan, BJK getiri serisinin en fazla kendi değerlerinden oluşan gecikmeli şoklardan ve XU100 getiri endeksinde meydana gelen şoklardan aynı yönde etkilendiği, ikinci gün ise etkisi ortadan kalkmaktadır.

Tablo 8. 3 Temmuz 2011 Öncesi GETIRIFB Varyans Ayrıştırması ve Etki-Tepki Analizi Sonuçları

\begin{tabular}{|c|c|c|c|c|c|}
\hline \multicolumn{4}{|c|}{ Varyans Ayrıştırması GETIRIFB } & \multicolumn{2}{c|}{ Etki-Tepki GETIRIFB } \\
\hline Dönem & Standart Hata & GETIRIFB & XU100GETIRI & GETIRIFB & XU100GETIRI \\
\hline $\mathbf{1}$ & 0.030964 & 100.0000 & 0.000000 & 0.030964 & 0.000000 \\
\hline $\mathbf{2}$ & 0.031276 & 99.64969 & 0.350315 & 0.003999 & 0.001851 \\
\hline $\mathbf{3}$ & 0.031598 & 99.13910 & 0.860903 & 0.003882 & $-0,002273$ \\
\hline $\mathbf{4}$ & 0.031619 & 99.13619 & 0.863814 & 0.001151 & $-0,000202$ \\
\hline $\mathbf{5}$ & 0.031624 & 99.13152 & 0.868483 & 0.000477 & $-0,000222$ \\
\hline $\mathbf{6}$ & 0.031624 & 99.13106 & 0.868945 & 0.000191 & $-7,06 \mathrm{E}-05$ \\
\hline $\mathbf{7}$ & 0.031625 & 99.13099 & 0.869011 & $7.02 \mathrm{E}-05$ & $-2,67 \mathrm{E}-05$ \\
\hline $\mathbf{8}$ & 0.031625 & 99.13098 & 0.869023 & $2.81 \mathrm{E}-05$ & $-1,13 \mathrm{E}-05$ \\
\hline $\mathbf{9}$ & 0.031625 & 99.13098 & 0.869025 & $1.07 \mathrm{E}-05$ & $-4,05 \mathrm{E}-06$ \\
\hline $\mathbf{1 0}$ & 0.031625 & 99.13097 & 0.869025 & $4.14 \mathrm{E}-06$ & $-1,63 \mathrm{E}-06$ \\
\hline
\end{tabular}

Tablo 8'de model değişkenlerinin kendi değerlerinde ortaya çıkan gecikmeli değişimler ile diğer değişkenlerde meydana gelen gecikmeli değişimlerden hangi oranda etkilendikleri ve ayrıca, bir değişkenin oynaklığında meydana gelen 1 standart sapmalık beklenmeyen değişimin veya şokun, kapsanan diğer değişkenlerin oynaklıkları üzerinde dönemler itibariyle yarattığı uzun süreli etkileri tespit etmek amacıyla varyans ayrıştırması ve etki-tepki analizi yapılmıştır.

Tablo 8 incelendiğinde şike soruşturması öncesi dönemde FB getiri serisinin oynaklığında meydana gelen değişimlerin \%99,13’ü kendi gecikmeli değişimlerinden kaynaklanmaktadır. XU100 endeksinin etkisi ise en fazla \%0,86 seviyesine ulaşmıştır. FB getiri serisinin daha çok kendi şoklarından etkilendiği ve bu etkinin, maksimum değerine ulaştığ 1 şoku takip eden ikinci gün sonunda tümüyle ortadan kalkarak ters yönde etkilendiği söylenebilir. Yine FB getiri serisinin XU100 getiri endeksinde meydana gelen şoklardan aynı yönde etkilendiği ve bu etkinin ikinci günde en yüksek değerine ulaştıktan sonra 3. günde neredeyse ortadan kalktığı söylenebilir.

Tablo 9. 3 Temmuz 2011 Sonrası GETIRIFB Varyans Ayrıștırması ve Etki-Tepki Analizi Sonuçları

\begin{tabular}{|c|c|c|c|c|c|}
\hline \multicolumn{4}{|c|}{ Varyans Ayrıştırması GETIRIFB } & \multicolumn{2}{c|}{ Etki-Tepki GETIRIFB } \\
\hline Dönem & Standart Hata & GETIRIFB & XU100GETIRI & GETIRIFB & XU100GETIRI \\
\hline $\mathbf{1}$ & 0.032688 & 100.0000 & 0.000000 & 0.032688 & 0.000000 \\
\hline $\mathbf{2}$ & 0.032831 & 99.84881 & 0.151188 & 0.002777 & $-0,001277$ \\
\hline $\mathbf{3}$ & 0.033049 & 99.51087 & 0.489131 & $-0,003262$ & 0.001927 \\
\hline $\mathbf{4}$ & 0.033065 & 99.44921 & 0.550790 & $-0,000647$ & 0.000824 \\
\hline $\mathbf{5}$ & 0.033125 & 99.35100 & 0.649004 & $-0,001691$ & 0.001049 \\
\hline $\mathbf{6}$ & 0.033129 & 99.33240 & 0.667600 & $-0,000188$ & 0.000453 \\
\hline $\mathbf{7}$ & 0.033133 & 99.32389 & 0.676113 & 0.000399 & $-0,000308$ \\
\hline $\mathbf{8}$ & 0.033133 & 99.32364 & 0.676363 & 0.000177 & $-5,46 \mathrm{E}-05$ \\
\hline $\mathbf{9}$ & 0.033134 & 99.32101 & 0.678994 & $9.65 \mathrm{E}-05$ & $-0,000171$ \\
\hline
\end{tabular}




\begin{tabular}{|l|l|l|l|l|l|}
$\mathbf{1 0}$ & 0.033134 & 99.32042 & 0.679581 & $-5,78 \mathrm{E}-06$ & $-8,05 \mathrm{E}-05$ \\
\hline
\end{tabular}

Tablo 9'de şike soruşturması sonrası dönem için FB getiri serisinin varyans ayrıştırması ve etki-tepki analizi sonuçları gösterilmiştir. Tablo 11 incelendiğinde, şike soruşturması öncesi döneme benzer şekilde FB getiri serisinin oynaklığında meydana gelen değişimlerin en az \%99,32 kendi gecikmeli değişimlerinden kaynaklanmaktadır. XU100 getirisinin etkisi en fazla \%0,67 seviyesindedir. Ayrıca, FB getiri serisinin en çok kendi şoklarından etkilendiği ve bu etkinin, maksimum değerine ulaştığı şoku takip eden ikinci günden sonra azaldığı altıncı günden sonra tümüyle ortadan kalkarak ters yönde etkilendiği söylenebilir. Diğer yandan, serinin XU100 değişkenindeki şoklara olan ters yönlü tepkisi altıncı gün en yüksek değerini alırken, 7. günde ortadan kalkmaktadır. Şike soruşturması sonrası dönemde FB getiri serisi hem kendi şoklarından hem de XU100 endeksindeki şoklardan daha uzun süre etkilendiği söylenebilir.

Tablo 10. 3 Temmuz 2011 Öncesi GETIRIGS Varyans Ayrıştırması ve Etki-Tepki Analizi Sonuçları

\begin{tabular}{|c|c|c|c|c|c|}
\hline \multicolumn{4}{|c|}{ Varyans Ayriştırması GETIRIGS } & \multicolumn{2}{c|}{ Etki-Tepki GETIRIGS } \\
\hline Dönem & Standart Hata & GETIRIGS & XU100GETIRI & GETIRIGS & XU100GETIRI \\
\hline $\mathbf{1}$ & 0.028805 & 100.0000 & 0.000000 & 0.028805 & 0.000000 \\
\hline $\mathbf{2}$ & 0.028819 & 99.98679 & 0.013205 & 0.000840 & 0.000331 \\
\hline $\mathbf{3}$ & 0.028819 & 99.98674 & 0.013259 & $2.87 \mathrm{E}-05$ & $2.11 \mathrm{E}-05$ \\
\hline $\mathbf{4}$ & 0.028819 & 99.98674 & 0.013259 & $1.11 \mathrm{E}-06$ & $1.06 \mathrm{E}-06$ \\
\hline $\mathbf{5}$ & 0.028819 & 99.98674 & 0.013259 & $4.59 \mathrm{E}-08$ & $4.95 \mathrm{E}-08$ \\
\hline $\mathbf{6}$ & 0.028819 & 99.98674 & 0.013259 & $1.97 \mathrm{E}-09$ & $2.24 \mathrm{E}-09$ \\
\hline $\mathbf{7}$ & 0.028819 & 99.98674 & 0.013259 & $8.61 \mathrm{E}-11$ & $1.00 \mathrm{E}-10$ \\
\hline $\mathbf{8}$ & 0.028819 & 99.98674 & 0.013259 & $3.79 \mathrm{E}-12$ & $4.47 \mathrm{E}-12$ \\
\hline $\mathbf{9}$ & 0.028819 & 99.98674 & 0.013259 & $1.68 \mathrm{E}-13$ & $1.98 \mathrm{E}-13$ \\
\hline $\mathbf{1 0}$ & 0.028819 & 99.98674 & 0.013259 & $7.43 \mathrm{E}-15$ & $8.81 \mathrm{E}-15$ \\
\hline
\end{tabular}

Tablo 10'da şike soruşturması öncesi dönem için GS getiri serisinin varyans ayrıştırması ve etki-tepki analizi sonuçları gösterilmiştir. Tablo 10'a göre, GS getiri oynaklığı değişiminin en az \%99,98 düzeyinde serinin kendi gecikmeli değerlerinden kaynaklandığı, buna karşın XU100 gecikmeli değişimlerinin neden olduğu aynı yönlü etkinin \%0,013’te çok düşük kaldığı anlaşılmaktadır. Tablo 12 incelediğinde, GS getiri serisinin kendi değerlerinde yaşanan şoklardan 1 dönem gecikmeli olarak en yüksek düzeyde doğru orantılı olarak etkilendiği ve bu etkinin takip eden ikinci gün içerisinde ciddi oranda azaldığı ve 3. günde ise ortadan kalktığı görülmüştür. Serinin XU100 getiri değişimlerindeki şoklardan etkilenme davranışı, nispeten az ve ikinci günün sonunda ortadan kalkmaktadır.

Tablo 11. 3 Temmuz 2011 Sonrası GETIRIGS Varyans Ayrıştırması ve Etki-Tepki Analizi Sonuçları

\begin{tabular}{|c|c|c|c|c|c|}
\hline \multicolumn{4}{|c|}{ Varyans Ayrıştırması GETIRIGS } & \multicolumn{2}{c|}{ Etki-Tepki GETIRIGS } \\
\hline Dönem & Standart Hata & GETIRIGS & XU100GETIRI & GETIRIGS & XU100GETIRI \\
\hline $\mathbf{1}$ & 0.050676 & 100.0000 & 0.000000 & 0.050676 & 0.000000 \\
\hline $\mathbf{2}$ & 0.050846 & 99.92922 & 0.070782 & 0.003927 & 0.001353 \\
\hline $\mathbf{3}$ & 0.050847 & 99.92912 & 0.070878 & 0.000246 & $5.04 \mathrm{E}-05$ \\
\hline $\mathbf{4}$ & 0.050847 & 99.92912 & 0.070879 & $1.68 \mathrm{E}-05$ & $4.53 \mathrm{E}-06$ \\
\hline $\mathbf{5}$ & 0.050847 & 99.92912 & 0.070879 & $1.11 \mathrm{E}-06$ & $2.67 \mathrm{E}-07$ \\
\hline $\mathbf{6}$ & 0.050847 & 99.92912 & 0.070879 & $7.43 \mathrm{E}-08$ & $1.88 \mathrm{E}-08$ \\
\hline $\mathbf{7}$ & 0.050847 & 99.92912 & 0.070879 & $4.94 \mathrm{E}-09$ & $1.23 \mathrm{E}-09$ \\
\hline $\mathbf{8}$ & 0.050847 & 99.92912 & 0.070879 & $3.30 \mathrm{E}-10$ & $8.26 \mathrm{E}-11$ \\
\hline $\mathbf{9}$ & 0.050847 & 99.92912 & 0.070879 & $2.20 \mathrm{E}-11$ & $5.48 \mathrm{E}-12$ \\
\hline $\mathbf{1 0}$ & 0.050847 & 99.92912 & 0.070879 & $1.46 \mathrm{E}-12$ & $3.66 \mathrm{E}-13$ \\
\hline
\end{tabular}

Tablo 11'de şike soruşturması sonrası dönem için GS getiri serisinin varyans ayrıştırması ve etki-tepki analizi sonuçları gösterilmiştir. Tablo 11'de GS getiri serisinin kendi gecikmeli değerlerinden en az \%99,92 düzeyinde 
etkilendiği, XU100 getiri serisinin gecikmeli değerlerinden etkilenme oranı ise en fazla \%0,07 düzeyine ulaşabildiği görülmektedir. GS getiri serisinin kendi gecikmeli değerlerinde yaşanan şoklardan aynı yönde etkilendiği, şoku takip eden ilk günde tavan yapan bu etkideki düşüşün 2. ve 3. günlerde azalan bir ivmeyle gerçekleştiği görülebilmektedir. Ayrıca GS getiri serisinin XU100 değişkenindeki şoklardan da aynı yönde etkilendiği, söz konusu etkinin şoku takip eden ikinci günde en yüksek değerine ulaştıktan sonra 3. günde ortadan kalktığı tespit edilmiştir

Tablo 12. 3 Temmuz 2011 Öncesi GETIRITS Varyans Ayrıştırması ve Etki-Tepki Analizi Sonuçları

\begin{tabular}{|c|c|c|c|c|c|}
\hline \multicolumn{4}{|c|}{ Varyans Ayrıştırması GETIRITS } & \multicolumn{2}{c|}{ Etki-Tepki GETIRITS } \\
\hline Dönem & Standart Hata & GETIRITS & XU100GETIRI & GETIRITS & XU100GETIRI \\
\hline $\mathbf{1}$ & 0.035887 & 100.0000 & 0.000000 & 0.035887 & 0.000000 \\
\hline $\mathbf{2}$ & 0.036156 & 99.99923 & 0.000765 & 0.004399 & 0.000100 \\
\hline $\mathbf{3}$ & 0.036160 & 99.99922 & 0.000783 & 0.000541 & $1.54 \mathrm{E}-05$ \\
\hline $\mathbf{4}$ & 0.036160 & 99.99922 & 0.000783 & $6.66 \mathrm{E}-05$ & $1.99 \mathrm{E}-06$ \\
\hline $\mathbf{5}$ & 0.036160 & 99.99922 & 0.000783 & $8.21 \mathrm{E}-06$ & $2.48 \mathrm{E}-07$ \\
\hline $\mathbf{6}$ & 0.036160 & 99.99922 & 0.000783 & $1.01 \mathrm{E}-06$ & $3.06 \mathrm{E}-08$ \\
\hline $\mathbf{7}$ & 0.036160 & 99.99922 & 0.000783 & $1.25 \mathrm{E}-07$ & $3.78 \mathrm{E}-09$ \\
\hline $\mathbf{8}$ & 0.036160 & 99.99922 & 0.000783 & $1.53 \mathrm{E}-08$ & $4.65 \mathrm{E}-10$ \\
\hline $\mathbf{9}$ & 0.036160 & 99.99922 & 0.000783 & $1.89 \mathrm{E}-09$ & $5.73 \mathrm{E}-11$ \\
\hline $\mathbf{1 0}$ & 0.036160 & 99.99922 & 0.000783 & $2.33 \mathrm{E}-10$ & $7.06 \mathrm{E}-12$ \\
\hline
\end{tabular}

Tablo 12'de şike soruşturması öncesi dönem için TS getiri serisinin varyans ayrıştırması ve etki-tepki analizi sonuçları gösterilmiştir. Tablo 12 incelendiğinde, TS getiri serisinin kendi gecikmeli değerlerinden en az \%99,999 düzeyinde etkilendiği, XU100 getiri serisinin gecikmeli değerlerinden etkilenme oranı ise en fazla \%0,0007 düzeyine ulaşabildiği anlaşılmıştır. Başka bir ifade ile şike soruşturması öncesi dönem için TS getiri serisinin en çok kendi şoklarından etkilenmektedir. TS getiri serisinin de en çok kendi şoklarından etkilendiği ve bu etkinin, ikinci günde önemli bir oranda ortadan kalkmaktadır. Serinin XU100 getirilerindeki şoklardan etkilenme düzeyi ise ters yönlüdür ve bu etkinin ikinci günde maksimum hale geldiği ve üçüncü günde ise ortadan kalktığı görülmektedir.

Tablo 13. 3 Temmuz 2011 Sonrası GETIRITS Varyans Ayrıştırması ve Etki-Tepki Analizi Sonuçları

\begin{tabular}{|c|c|c|c|c|c|}
\hline \multicolumn{9}{|c|}{ Varyans Ayrıstırması GETIRITS } & \multicolumn{2}{c|}{ Etki-Tepki GETIRITS } \\
\hline Dönem & Standart Hata & GETIRITS & XU100GETIRI & GETIRITS & XU100GETIRI \\
\hline $\mathbf{1}$ & 0.033858 & 100.0000 & 0.000000 & 0.033858 & 0.000000 \\
\hline $\mathbf{2}$ & 0.034372 & 99.09788 & 0.902121 & 0.004942 & $-0,003265$ \\
\hline $\mathbf{3}$ & 0.034402 & 98.95812 & 1.041879 & 0.000633 & 0.001293 \\
\hline $\mathbf{4}$ & 0.034404 & 98.95597 & 1.044031 & 0.000310 & $-0,000164$ \\
\hline $\mathbf{5}$ & 0.034458 & 98.70182 & 1.298184 & $-0,000784$ & 0.001748 \\
\hline $\mathbf{6}$ & 0.034568 & 98.40576 & 1.594243 & $-0,001996$ & $-0,001907$ \\
\hline $\mathbf{7}$ & 0.034737 & 98.42122 & 1.578784 & $-0,003423$ & $1.70 \mathrm{E}-05$ \\
\hline $\mathbf{8}$ & 0.034759 & 98.40682 & 1.593181 & $-0,001142$ & 0.000445 \\
\hline $\mathbf{9}$ & 0.034765 & 98.37753 & 1.622465 & $-0,000279$ & $-0,000601$ \\
\hline $\mathbf{1 0}$ & 0.034767 & 98.36900 & 1.630996 & $-0,000164$ & 0.000324 \\
\hline
\end{tabular}

Tablo 13'te şike soruşturması sonrası dönem için TS getiri serisinin varyans ayrıştırması ve etki-tepki analizi sonuçları gösterilmiştir. Tablo 13 incelendiğinde, TS getiri serisinin kendi gecikmeli değerlerinden en az \%98,36 düzeyinde etkilendiği, XU100 getiri serisinin gecikmeli değerlerinden etkilenme oranı ise en fazla \%1,63 düzeyine ulaşabildiği anlaşılmıştır. Şike öncesi döneme göre şike sonrası dönem XU100 getiri serisinin öngörülen etkisinin nispeten daha belirgin hale geldiği görülmüştür. Diğer yandan, TS getiri serisinin kendi şoklarına olan aynı yönlü tepkisinin ilk günde maksimum düzeye ulaştı̆̆ı ve ikinci günden itibaren azalmaya başladığı tespit edilmiştir. Buna karşın, TS getiri serisinin XU100 getiri serisindeki şoklara üçüncü günde ters tepki verdiği ve bir sonraki günde ise etkide pozitif yönlü bir artış yaşandığ izlenmektedir. 
Elitaş, C., Doğan, M., Karahan, Ö. / Journal of Yasar University, 2016, 11/42, 84-101

Tablo 14. 3 Temmuz 2011 Öncesi Granger Nedensellik Testi Sonuçları

\begin{tabular}{|c|c|c|c|c|c|c|c|c|c|c|c|}
\hline \multirow{2}{*}{ 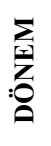 } & \multirow{2}{*}{ NEDENSELLIKK İLİŞKİSİ } & \multicolumn{2}{|c|}{1 gün } & \multicolumn{2}{|c|}{2 gün } & \multicolumn{2}{|c|}{3 gün } & \multicolumn{2}{|c|}{4 gün } & \multicolumn{2}{|c|}{5 gün } \\
\hline & & $\mathbf{F}$ & Prob & $\mathbf{F}$ & Prob & $\mathbf{F}$ & Prob & $\mathbf{F}$ & Prob & $\mathbf{F}$ & Prob \\
\hline \multirow{8}{*}{ 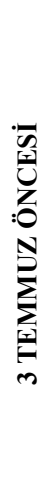 } & GETIRIBJK ==> XU100GETIRI & 0,65 & 0,42 & 3,54 & 0,03 & 2,54 & 0,06 & 1,94 & 0,1 & 1,57 & 0,16 \\
\hline & XU100GETIRI ==> GETIRIBJK & 0,08 & 0,78 & 0,72 & 0,48 & 0,67 & 0,57 & 0,92 & 0,45 & 0,71 & 0,6 \\
\hline & GETIRIFB $==>$ XU100GETIRI & 0,33 & 0,56 & 1,66 & 0,19 & 1,38 & 0,25 & 1,11 & 0,35 & 1,21 & 0,3 \\
\hline & XU100GETIRI ==> GETIRIFB & 1,5 & 0,22 & 2,85 & 0,06 & 2,85 & 0,04 & 2,4 & 0,05 & 1,94 & 0,08 \\
\hline & GETIRIGS $==>$ XU100GETIRI & 0,07 & 0,79 & 1,23 & 0,29 & 1,07 & 0,36 & 0,74 & 0,56 & 0,83 & 0,52 \\
\hline & XU100GETIRI ==> GETIRIGS & 0,07 & 0,79 & 0,38 & 0,69 & 0,31 & 0,82 & 0,96 & 0,43 & 0,96 & 0,44 \\
\hline & GETIRITS $==>$ XU100GETIRI & 0,71 & 0,4 & 1,48 & 0,22 & 1,24 & 0,29 & 2,28 & 0,06 & 1,83 & 0,11 \\
\hline & XU100GETIRI ==> GETIRITS & 0,01 & 0,95 & 0,02 & 0,97 & 0,18 & 0,91 & 0,51 & 0,73 & 0,47 & 0,8 \\
\hline
\end{tabular}

Tablo 15. 3 Temmuz 2011 Sonrası Granger Nedensellik Testi Sonuçları

\begin{tabular}{|c|c|c|c|c|c|c|c|c|c|c|c|}
\hline \multirow{2}{*}{ 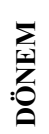 } & \multirow{2}{*}{ NEDENSELLİK İLİŞKİSİ } & \multicolumn{2}{|c|}{1 gün } & \multicolumn{2}{|c|}{2 gün } & \multicolumn{2}{|c|}{3 gün } & \multicolumn{2}{|c|}{4 gün } & \multicolumn{2}{|c|}{5 gün } \\
\hline & & $\mathbf{F}$ & Prob & $\mathbf{F}$ & Prob & $\mathbf{F}$ & Prob & $\mathbf{F}$ & Prob & $\mathbf{F}$ & Prob \\
\hline \multirow{8}{*}{ 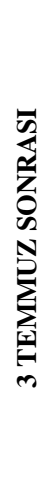 } & GETIRIBJK ==> XU100GETIRI & 0,34 & 0,56 & 0,25 & 0,78 & 0,35 & 0,79 & 0,25 & 0,91 & 0,59 & 0,71 \\
\hline & XU100GETIRI ==> GETIRIBJK & 0,52 & 0,47 & 0,36 & 0,7 & 0,39 & 0,76 & 0,59 & 0,67 & 0,54 & 0,75 \\
\hline & GETIRIFB ==> XU100GETIRI & 0,52 & 0,47 & 0,94 & 0,39 & 0,78 & 0,51 & 0,62 & 0,65 & 0,49 & 0,78 \\
\hline & XU100GETIRI ==> GETIRIFB & 0,62 & 0,43 & 1,53 & 0,22 & 1,19 & 0,31 & 0,97 & 0,41 & 1,18 & 0,32 \\
\hline & GETIRIGS $==>$ XU100GETIRI & 0,16 & 0,69 & 0,16 & 0,85 & 0,11 & 0,95 & 0,09 & 0,99 & 0,08 & 0,99 \\
\hline & XU100GETIRI ==> GETIRIGS & 0,4 & 0,53 & 0,45 & 0,64 & 0,46 & 0,71 & 0,43 & 0,79 & 0,34 & 0,89 \\
\hline & GETIRITS ==> XU100GETIRI & 2,96 & 0,09 & 1,7 & 0,18 & 1,63 & 0,18 & 1,39 & 0,24 & 1,74 & 0,12 \\
\hline & XU100GETIRI $==>$ GETIRITS & 4,42 & 0,04 & 2,65 & 0,07 & 1,5 & 0,21 & 1,47 & 0,21 & 1,96 & 0,08 \\
\hline
\end{tabular}

Tablo 14 ve 15'te 1-5 gün gecikme dönemi için Granger Nedensellik Testi sonuçları gösterilmiştir. Şike soruşturmas1 öncesi ve sonrası dönem için kulüp getirilerinden endeks getirilerine, endeks getirilerinden de kulüp getirilerine doğru çoğu zaman istatistiksel olarak anlamlı olmayan bir ilişki tespit edilmiştir. 3 Temmuz öncesi test sonuçlarına göre; istatistiksel olarak anlamlı bir ilişki olmasa da FB getiri serisinden endeks getiri serisine doğru bir ilişki mevcuttur. XU100 endeks getirisinden FB getirisine doğru olan etkiler ise XU100 endeks getirisinden diğer kulüp getirilerine doğru olan etkilere kıyasla daha anlamlıdır. Buna karşın 3 Temmuz sonrası analiz döneminde ise, TS getiri serisinden XU100 endeks getiri serisine doğru olan etkiler, diğer kulüp getiri serilerinden endeks getiri serisine doğru olan etkilere kıyasla daha anlamlıdır. XU100 endeks getirisi ile kulüp getirileri arasındaki ilişkilere bakıldığında ise TS getirilerine doğru olan etkilerin daha anlamlı olduğu gözlenmektedir.

Tablo 16. Eşbütünleşme Denklemlerinin Katsayıları

\begin{tabular}{|c|c|}
\hline 3 TEMMUZ ÖNCESI & 3 TEMMUZ SONRASI \\
\hline GETIRIBJK $=12,76($ XU100GETIRI $)$ & GETIRIBJK $=0,765($ XU100GETIRI $)$ \\
\hline GETIRIFB $=10,28($ XU100GETIRI) & GETIRIFB $=0,236($ XU100GETIRI $)$ \\
\hline GETIRIGS $=0,938($ XU100GETIRI $)$ & GETIRIGS $=38,67($ XU100GETIRI) \\
\hline GETIRITS $=9,687($ XU100GETIRI) & GETIRITS $=0,642($ XU100GETIRI) \\
\hline
\end{tabular}

Tablo 16 incelendiğinde şike soruşturması öncesinde XU100 getirilerindeki \%1'lik değişimin BJK getirilerinde aynı yönlü \%12,76'lık bir değişime neden olduğu görülebilmektedir. 3 Temmuz 2011 sonrasında ise bu oran \%0,76'ya gerilemiştir. Benzer şekilde şike soruşturması öncesinde XU100 getirilerindeki \%1'lik değişimin FB ve TS getirilerinde 
aynı yönlü sırasıyla \%10,28'lik ve \%9,68'lik bir değişime neden olmaktadır. 3 Temmuz 2011 sonrasında ise bu oranlar sırasıyla \%0,23'e ve \%0,64'e gerilemiştir. XU100 getirilerindeki \%1'lik değişim şike soruşturmasına dâhil olmayan GS getirilerinde ise diğer spor kulüplerinden farklı olarak şike öncesi dönemde \%0,93'lük ve şike sonrası dönemde ise \%38,67'lik bir değişim yaratmaktadır.

Tablo 17. ARCH-LM Sonuçları

\begin{tabular}{|c|c|c|c|c|c|c|c|c|}
\hline \multirow{2}{*}{ DEĞIŞKEN } & \multicolumn{3}{|c|}{3 Temmuz 2011 Öncesi } & \multicolumn{3}{c|}{3 Temmuz 2011 Sonrası } \\
\cline { 2 - 9 } & F-st. & Prob & Obs*R-sqrd & Prob & F-st. & Prob & Obs*R-sqrd & Prob \\
\hline GETIRIBJK - XU100GETIRI & 52,0796 & 0,0000 & 88,2945 & 0,0000 & 9,4774 & 0,0022 & 9,3534 & 0,0022 \\
\hline GETIRIFB - XU100GETIRI & 14,7257 & 0,0000 & 28,1297 & 0,0000 & 10,2720 & 0,0000 & 38,6047 & 0,0000 \\
\hline GETIRIGS - XU100GETIRI & 2,7346 & 0,0987 & 2,7310 & 0,0984 & 0,0010 & 0,9752 & 0,0010 & 0,9751 \\
\hline GETIRITS - XU100GETIRI & 64,8899 & 0,0000 & 58,3801 & 0,0000 & 10,2617 & 0,0000 & 56,0943 & 0,0000 \\
\hline
\end{tabular}

Tablo 17'de verilerde Otoregresif Koşullu Değişen Varyans (ARCH) etkilerinin mevcut olup olmadığının test etmek amacıyla ARCH-LM testinin sonuçları gösterilmiştir. Tablo 17 incelendiğinde şike soruşturması öncesinde ve sonrasında GS hisse senedi getirileri için otokorelasyon olmadığı diğer spor kulüpleri için ise hem şike soruşturması öncesinde hem de sonrasında otokorelasyonun olduğu görülmektedir.

Tablo 18. BJK Getiri Serisi Model Performans Sonuçları

\begin{tabular}{|l|c|c|c|c|c|c|}
\hline \multirow{2}{*}{ DEĞIŞKEN: GETIRIBJK } & \multicolumn{2}{|c|}{3 Temmuz 2011 Öncesi } & \multicolumn{2}{c|}{ 3 Temmuz 2011 Sonrası } \\
\hline MODEL & $\begin{array}{c}\text { Log- } \\
\text { Likelihood }\end{array}$ & AIC & SC & $\begin{array}{c}\text { Log- } \\
\text { Likelihood }\end{array}$ & AIC & SC \\
\hline TARCH (1,1) & 1035,158 & $-3,6430$ & $-3,5969$ & 1143,927 & $-4,028$ & $-3,9820$ \\
\hline EGARCH (1,1) & 1053,002 & $-3,7062$ & $-3,6601$ & 1129,451 & $-3,9768$ & $-3,9307$ \\
\hline PARCH (1,1) & 1053,536 & $-3,7045$ & $-3,6508$ & 1141,295 & $-4,0152$ & $-3,9614$ \\
\hline
\end{tabular}

Tablo 18 'de BJK getiri serisi için oynaklık tahmin modellerine ait model performans sonuçları yer almaktadır. 3 Temmuz 2011 tarihinde başlayan şike soruşturması, Borsa İstanbul'da işlem gören Beşiktaş'ın hisse senedi getirisinde önemli değişimlere neden olmamıştır. Tabloda yer alan performans ölçütleri incelendiğinde şike soruşturma öncesindeki dönem için PARCH, sonrası için ise TARCH modeli daha uygundur.

Tablo 19. 3 Temmuz 2011 Öncesi ve Sonrası BJK Getiri Serisinde Asimetri Etkisi ve Oynaklık Kümelenmesi Sonuçları

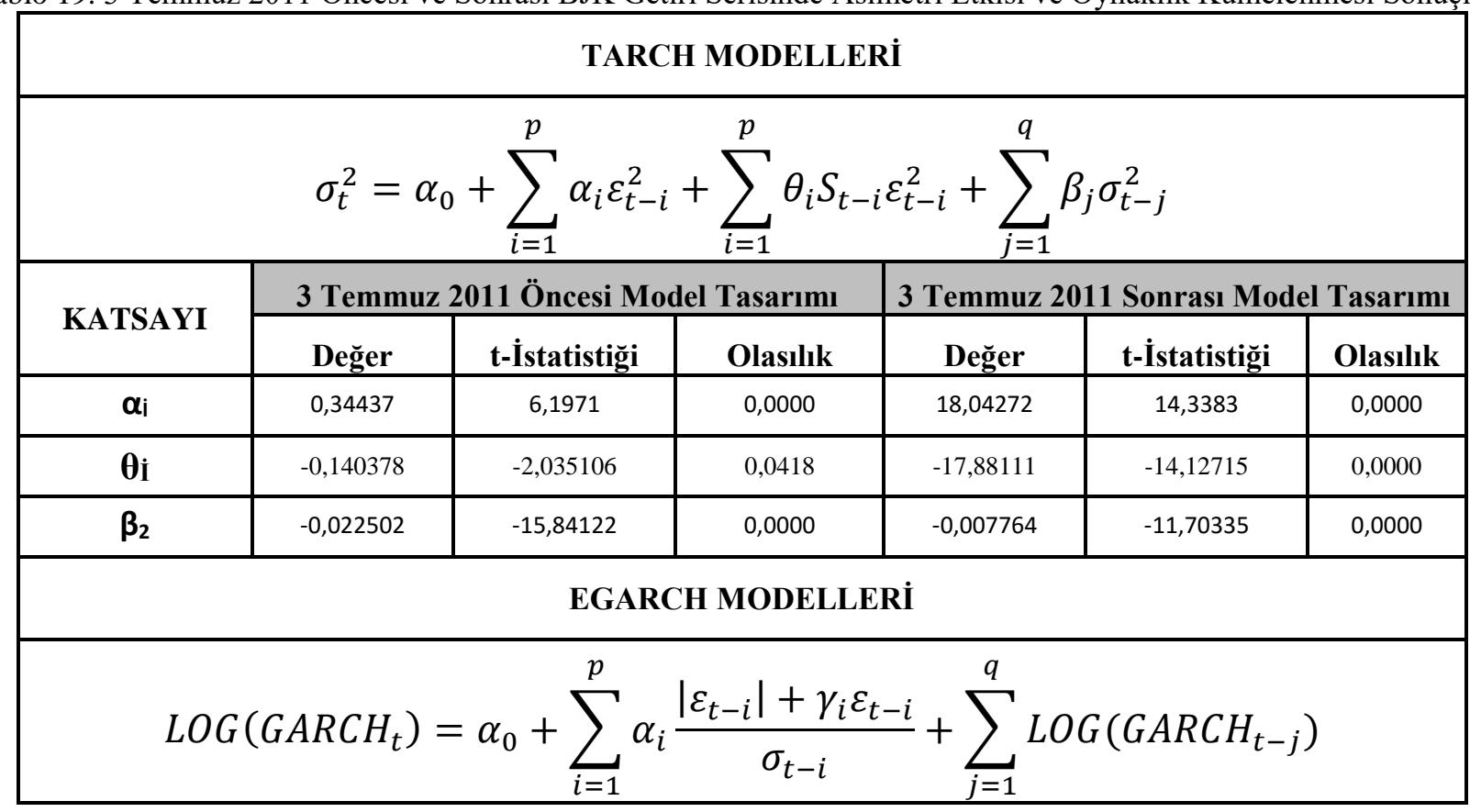


Elitaş, C., Doğan, M., Karahan, Ö. / Journal of Yasar University, 2016, 11/42, 84-101

\begin{tabular}{|c|c|c|c|c|c|c|}
\hline \multirow{2}{*}{ KATSAYI } & \multicolumn{3}{|c|}{3 Temmuz 2011 Öncesi Model Tasarımı } & \multicolumn{3}{|c|}{3 Temmuz 2011 Sonrası Model Tasarımı } \\
\hline & Değer & t-İstatistiği & Olasılık & Değer & t-İstatistiği & Olasılık \\
\hline$\alpha_{\mathrm{i}}$ & 0,430382 & 9,116672 & 0,0000 & 1,099825 & 24,66753 & 0,0000 \\
\hline$\gamma_{\mathrm{i}}$ & 0,0535 & 1,787665 & 0,0738 & 1,254532 & 35,40024 & 0,0000 \\
\hline $\boldsymbol{\beta}_{2}$ & $-7,913498$ & $-4,102317$ & 0,0000 & $-8,463875$ & $-6,467862$ & 0,0000 \\
\hline \multicolumn{7}{|c|}{ PARCH MODELLERİ } \\
\hline \multicolumn{7}{|c|}{$\sigma_{t}^{y}=\alpha_{0}+\sum_{i=1} \alpha_{i}\left(\left|\varepsilon_{t-i}\right|-\delta_{i} \varepsilon_{t-i}\right)^{y}+\sum_{j=1} \beta_{j} \sigma_{t-j}^{y}$} \\
\hline \multirow{2}{*}{ KATSAYI } & \multicolumn{3}{|c|}{3 Temmuz 2011 Öncesi Model Tasarımı } & \multicolumn{3}{|c|}{3 Temmuz 2011 Sonrası Model Tasarımı } \\
\hline & Değer & t-İstatistiği & Olasılık & Değer & t-İstatistiğ $\mathbf{i}$ & Olasılık \\
\hline $\boldsymbol{\alpha}_{\mathbf{i}}$ & 0,403906 & 7,636824 & 0,0000 & 0,967964 & 5,840618 & 0,0000 \\
\hline$\delta_{\mathrm{i}}$ & $-0,051198$ & $-0,880909$ & 0,3784 & $-0,893761$ & $-34,61876$ & 0,0000 \\
\hline$\gamma$ & 1,749147 & 6,121893 & 0,0000 & 0,59806 & 5,132910 & 0,0000 \\
\hline $\boldsymbol{\beta}_{2}$ & $-0,030566$ & $-1,11474$ & 0,265 & $-0,661106$ & $-3,73851$ & 0,0002 \\
\hline
\end{tabular}

Tablo 19'da 3 Temmuz 2011 öncesi ve sonrası BJK getiri serisinde asimetri etkisi ve oynaklık kümelenmesi sonuçları gösterilmiştir. Bununla birlikte, Tablo 19'da yer alan 3 Temmuz öncesi TARCH sonuçlarına göre, ilgili parametrenin ( $\theta$ ) sıfırdan farklı ve anlamlı olduğunun tespiti nedeniyle asimetrik etkinin söz konusu olduğu söylenebilir. Ancak, parametre değeri negatif olduğundan modelde kaldıraç etkisi bulunmamaktadır. 3 Temmuz sonrası TARCH sonuçlarına göre ise, ilk dönemde olduğu gibi olumlu ve olumsuz haberlerin BJK getiri oynaklığı üzerindeki etkisinin birbirinden farklı olduğu anlaşılmaktadır. Her iki dönemde de olumlu haberlerin oynaklık üzerindeki etkisinin daha fazla olduğu gözlenmesine rağmen $(\alpha \mathrm{i}>0, \theta \mathrm{i}<0), 3$ Temmuz sonrası döneme ait etkilerde bariz bir artışın olduğu görülmektedir.

BJK için tahmin edilmiş ve 3 Temmuz öncesine ait EGARCH modeline bakıldığında, asimetri parametresi istatistiksel olarak anlamlıdır, ancak değeri pozitif olduğu için modelde kaldıraç etkisi söz konusu değildir. 3 Temmuz sonrası sonuçlarını incelediğimizde ise, asimetri etkisinin var olduğu fakat kaldıraç etkisinin mevcut olmadığı görülebilmektedir. Olumlu haberlerin oynaklık üzerindeki etkisinin şike soruşturması öncesi döneme göre daha yüksek olduğu anlaşılmaktadır.

PARCH model sonuçları incelendiğinde şike soruşturması öncesine ait PARCH sonuçlarına göre, asimetri parametresinin ( $\delta \dot{I})$ anlamlı olmadığı anlaşılmıştır. Başka bir ifadeyle, olumlu ve olumsuz haberlerin BJK'nin getiri oynaklığı üzerindeki etkileri birbirinden farklı değildir. Şike soruşturması sonrası dönemde ise, $\delta$ İ parametresinin anlamlı ve sıfırdan farklı bir değer aldığ 1 görülmektedir. Başka bir ifadeyle, modelde anlamlı bir asimetri etkisi tespit edilmiştir. Ancak, parametrenin negatif değerde olması kaldıraç etkisinin var olmadığını göstermektedir. Olumlu şokların oynaklık üzerindeki etkisinin daha fazla olduğu söylenebilir.

$\beta_{2}$ değerleri incelendiğinde TARCH ve EGARCH yöntemlerinde Ulusal 100 getirilerinde meydana gelen artışların BJK getiri oynaklığını ters yönde etkilemektedir. PARCH modelinde de ters yönde etkilemektedir ancak bu ilişki istatistiksel olarak anlamlı değildir. 
Elitaş, C., Doğan, M., Karahan, Ö. / Journal of Yasar University, 2016, 11/42, 84-101

Tablo 20. FB Getiri Serisi Model Performans Sonuçları

\begin{tabular}{|l|c|c|c|c|c|c|}
\hline \multirow{2}{*}{ DEĞIŞKEN: GETIRIFB } & \multicolumn{2}{|c|}{ 3 Temmuz 2011 Öncesi } & \multicolumn{2}{c|}{ 3 Temmuz 2011 Sonrası } \\
\hline MODEL & $\begin{array}{c}\text { Log- } \\
\text { Likelihood }\end{array}$ & AIC & SC & $\begin{array}{c}\text { Log- } \\
\text { Likelihood }\end{array}$ & AIC & SC \\
\hline TARCH (1,1) & 1258,707 & $-4,4343$ & $-4,3883$ & 1217,411 & $-4,2881$ & $-4,2421$ \\
\hline EGARCH (1,1) & 1260,268 & $-4,4398$ & $-4,3938$ & 1241,273 & $-4,3726$ & $-4,3265$ \\
\hline PARCH (1,1) & 1185,867 & $-4,1729$ & $-4,1192$ & 1253,902 & $-4,4138$ & $-4,3600$ \\
\hline
\end{tabular}

Tablo 20'de FB getiri serisi için oynaklık tahmin modellerine ait model performans sonuçları yer almaktadır. FB getiri serilerine ait oynaklık model performanslarını incelediğimizde, model performanslarının şike soruşturması öncesinde ve sonrasında bariz bir düşüş göstermemiş ve şike soruşturması öncesine göre hisse senedinin daha riskli ve öngörülemez hale geldiğini söylenemez. Tabloda yer alan performans ölçütleri ile ARCH ve GARCH parametre katsayılarının işaretleri dikkate alındığında, her iki dönemde de PARCH modellerinin üstünlüğü göze çarpmaktadır. Tabloda yer alan performans ölçütleri (yüksek Log-Likelihood, düşük AIC/SC değerleri) ve ARCH ve GARCH parametre katsayılarının işaretleri dikkate alındığında, soruşturma öncesindeki dönem için EGARCH, sonrası için ise PARCH modeli daha uygundur.

Tablo 21. 3 Temmuz 2011 Öncesi ve Sonrası FB Getiri Serisinde Asimetri Etkisi ve Oynaklık Kümelenmesi Sonuçları

\begin{tabular}{|c|c|c|c|c|c|c|}
\hline \multicolumn{7}{|c|}{ TARCH MODELLERİ } \\
\hline \multicolumn{7}{|c|}{$\sigma_{t}^{2}=\alpha_{0}+\sum_{i=1}^{r} \alpha_{i} \varepsilon_{t-i}^{2}+\sum_{i=1}^{r} \theta_{i} S_{t-i} \varepsilon_{t-i}^{2}+\sum_{j=1}^{1} \beta_{j} \sigma_{t-j}^{2}$} \\
\hline \multirow{2}{*}{ KATSAYI } & \multicolumn{3}{|c|}{3 Temmuz 2011 Öncesi Model Tasarımı } & \multicolumn{3}{|c|}{$\begin{array}{c}3 \text { Temmuz } 2011 \text { Sonrasi Model } \\
\text { Tasarımı }\end{array}$} \\
\hline & Değer & t-İstatistiği & Olasılık & Değer & t-İstatistiği & Olasılık \\
\hline$\alpha_{i}$ & 0,708616 & 9,60806 & 0,0000 & 0,233466 & 6,393210 & 0,0000 \\
\hline $\boldsymbol{\theta} \dot{\mathbf{I}}$ & $-0,401205$ & $-4,863465$ & 0,0000 & $-0,137632$ & $-3,280413$ & 0,0010 \\
\hline $\boldsymbol{\beta}_{\mathbf{2}}$ & $-0,00667$ & $-12,5384$ & 0,0000 & $-0,004076$ & $-5,241791$ & 0,0000 \\
\hline \multicolumn{7}{|c|}{ EGARCH MODELLERİ } \\
\hline \multicolumn{7}{|c|}{$L O G\left(G A R C H_{t}\right)=\alpha_{0}+\sum \alpha_{i} \frac{\left|\varepsilon_{t-i}\right|+\gamma_{i} \varepsilon_{t-i}}{\sigma_{t-i}}+\sum \operatorname{LOG}\left(G A R C H_{t-j}\right)$} \\
\hline \multirow{2}{*}{ KATSAYI } & \multicolumn{3}{|c|}{3 Temmuz 2011 Öncesi Model Tasarımı } & \multicolumn{3}{|c|}{$\begin{array}{c}3 \text { Temmuz } 2011 \text { Sonrasi Model } \\
\text { Tasarımı }\end{array}$} \\
\hline & Değer & t-İstatistiği & Olasılık & Değer & t-İstatistiği & Olasılık \\
\hline $\boldsymbol{\alpha} \dot{\mathbf{I}}$ & 0,529308 & 12,88326 & 0,0000 & 0,064738 & 3,500633 & 0,0005 \\
\hline$\gamma \dot{\mathbf{I}}$ & 0,201716 & 7,41626 & 0,0000 & 0,10956 & 6,485801 & 0,0000 \\
\hline $\boldsymbol{\beta}_{2}$ & $-20,42578$ & $-8,26474$ & 0,0000 & $-11,51586$ & $-10,50788$ & 0,0000 \\
\hline \multicolumn{7}{|c|}{ PARCH MODELLERİ } \\
\hline \multicolumn{7}{|c|}{$\sigma_{t}^{y}=\alpha_{0}+\sum_{i=1} \alpha_{i}\left(\left|\varepsilon_{t-i}\right|-\delta_{i} \varepsilon_{t-i}\right)^{y}+\sum_{j=1} \beta_{j} \sigma_{t-j}^{y}$} \\
\hline \multirow{2}{*}{ KATSAYI } & \multicolumn{3}{|c|}{3 Temmuz 2011 Öncesi Model Tasarımı } & \multicolumn{3}{|c|}{$\begin{array}{c}3 \text { Temmuz } 2011 \text { Sonrası Model } \\
\text { Tasarımı }\end{array}$} \\
\hline & Değer & t-İstatistiği & Olasılık & Değer & t-İstatistiği & Olasılık \\
\hline
\end{tabular}


Elitaş, C., Doğan, M., Karahan, Ö. / Journal of Yasar University, 2016, 11/42, 84-101

\begin{tabular}{|l|l|l|l|l|l|l|}
$\boldsymbol{\alpha} \dot{\mathbf{I}}$ & 0,145803 & 2,39454 & 0,0166 & 0,09713 & 5,671512 & 0,0000 \\
\hline $\boldsymbol{\delta} \dot{\mathbf{I}}$ & 0,049402 & 0,360892 & 0,7182 & $-0,86251$ & $-15,82725$ & 0,0000 \\
\hline $\boldsymbol{\gamma}$ & 1,960111 & 6,394403 & 0,0000 & 0,210884 & 2,285553 & 0,0223 \\
\hline $\boldsymbol{\beta}_{\mathbf{2}}$ & $-0,02114$ & $-0,980454$ & 0,3269 & $-0,66354$ & $-0,098121$ & 0,0000 \\
\hline
\end{tabular}

Tablo 21'de 3 Temmuz 2011 öncesi ve sonrası FB getiri serisinde asimetri etkisi ve oynaklık kümelenmesi sonuçları gösterilmiştir. Şike soruşturması öncesine ait TARCH sonuçlarına göre, asimetri parametresinin ( $\theta)$ anlamlı olduğu anlaşılmıştır. Başka bir ifadeyle, olumlu haberlerin olumsuz haberlere göre FB'nin getiri oynaklığg üzerindeki etkileri daha fazladır. Şike soruşturması sonrası dönemde ise, $\theta$ parametresinin anlamlı ve sıfırdan farklı bir değer aldığı görülmektedir. Başka bir ifade ile modelde anlamlı bir asimetri etkisi tespit edilmiştir. Ancak, parametrenin negatif değerde olması kaldıraç etkisinin var olmadığını göstermektedir. Olumlu şokların olumsuz şoklara göre oynaklık üzerindeki etkisinin daha fazla olduğu söylenebilir.

FB için 3 Temmuz öncesine ait EGARCH modeline bakıldığında, FB'ye ait şike soruşturması öncesi EGARCH modelinde tüm parametrelerin anlamlı olduğu görülmektedir. Ayrıca, $(\gamma)$ parametresi sıfırdan anlamlı bir şekilde farklı olduğundan asimetri etkisi söz konusudur. Fakat parametre değeri pozitif olduğu için kaldıraç etkisi bulunmamaktadır. Aynı durum soruşturma sonrası döneme ait EGARCH modelinde de görülebilmektedir. Ancak, olumlu haberlerin oynaklık üzerindeki etkisinin şike soruşturması sonrası dönemin şike soruşturması öncesi döneme göre bariz bir şekilde azaldığı söylenebilir.

Şike soruşturması öncesi dönemde FB getiri serisine ait PARCH sonuçları incelendiğinde \%5 düzeyinde asimetri ve kaldıraç etkilerinin bulunmadığ görülmektedir. Başka bir deyişle, olumlu ve olumsuz haberlerin oynaklık üzerindeki etkileri farklı değildir. Ayrıca, güç parametresinin anlamlılığı oynaklık kümelenmesinin varlığını destekleyen bir bulgudur. Şike soruşturması sonrası FB getiri serisine ait PARCH sonuçlarını incelediğimizde ise, $\delta$ parametresinin anlamlı çıkması asimetri etkisinin varlığına işaret etmektedir. Bununla birlikte, olumsuz şokların oynaklık üzerindeki etkisi olumlu şoklara göre daha fazladır. Modelde yer alan güç parametresi \%5 düzeyinde anlamlı bulunmuştur.

$\beta_{2}$ değerleri incelendiğinde tüm modellerde (TARCH, EGARCH ve PARCH) Ulusal 100 getirilerinde meydana gelen artışların FB getiri oynaklığını ters yönde etkilemektedir. Her üç modelde de istatistiksel olarak anlamlı bir ilişki vardır.

Tablo 22. GS Getiri Serisi Model Performans Sonuçları

\begin{tabular}{|l|c|c|c|c|c|c|}
\hline $\begin{array}{l}\text { DEĞIŞKEN: } \\
\text { GETIRIGS }\end{array}$ & \multicolumn{2}{|c|}{ 3 Temmuz 2011 Öncesi } & \multicolumn{2}{c|}{ 3 Temmuz 2011 Sonrası } \\
\hline MODEL & $\begin{array}{c}\text { Log- } \\
\text { Likelihood }\end{array}$ & AIC & SC & $\begin{array}{c}\text { Log- } \\
\text { Likelihood }\end{array}$ & AIC & SC \\
\hline TARCH (1,1) & 1262,866 & $-4,449$ & $-4,403$ & 873,6850 & $-3,0714$ & $-3,0253$ \\
\hline EGARCH (1,1) & 1272,508 & $-4,4832$ & $-4,4371$ & 964,4504 & $-3,3927$ & $-3,3466$ \\
\hline PARCH (1,1) & 1286,15 & $-4,5279$ & $-4,4742$ & 831,0691 & $-2,917$ & $-2,8633$ \\
\hline
\end{tabular}

Tablo 22'de GS getiri serisi için oynaklık tahmin modellerine ait model performans sonuçları yer almaktadır. Tabloda yer alan performans ölçütleri incelendiğinde şike soruşturma öncesindeki dönem için PARCH, sonrası için ise EGARCH modelinin en iyi model olarak kabul edilebileceği sonucuna ulaşılmıştır. 
Tablo 23. 3 Temmuz 2011 Öncesi ve Sonrası GS Getiri Serisinde Asimetri Etkisi ve Oynaklık Kümelenmesi Sonuçları

\begin{tabular}{|c|c|c|c|c|c|c|}
\hline \multicolumn{7}{|c|}{ TARCH MODELLERİ } \\
\hline \multicolumn{7}{|c|}{$\sigma_{t}^{2}=\alpha_{0}+\sum_{i=1} \alpha_{i} \varepsilon_{t-i}^{2}+\sum_{i=1} \theta_{i} S_{t-i} \varepsilon_{t-i}^{2}+\sum_{j=1} \beta_{j} \sigma_{t-j}^{2}$} \\
\hline \multirow{2}{*}{ KATSAYI } & \multicolumn{3}{|c|}{3 Temmuz 2011 Öncesi Model Tasarımı } & \multicolumn{3}{|c|}{3 Temmuz 2011 Sonrası Model Tasarımı } \\
\hline & Değer & t-İstatistiği & Olasılık & Değer & t-İstatistiği & Olasılık \\
\hline$\alpha_{i}$ & 0,329981 & 6,462789 & 0,0000 & $-0,128841$ & $-1,586045$ & 0,1127 \\
\hline$\theta \dot{\mathbf{I}}$ & $-0,386053$ & $-6,783115$ & 0,0000 & 0,129856 & 1,55382 & 0,1202 \\
\hline $\boldsymbol{\beta}_{\mathbf{2}}$ & $-0,00467$ & $-8,647421$ & 0,0000 & $-0,065232$ & $-28,64969$ & 0,0000 \\
\hline \multicolumn{7}{|c|}{ EGARCH MODELLERİ } \\
\hline \multicolumn{7}{|c|}{$\operatorname{LOG}\left(G A R C H_{t}\right)=\alpha_{0}+\sum_{i=1}^{r} \alpha_{i} \frac{\left|\varepsilon_{t-i}\right|+\gamma_{i} \varepsilon_{t-i}}{\sigma_{t-i}}+\sum_{j=1}^{T}$} \\
\hline \multirow{2}{*}{ KATSAYI } & \multicolumn{3}{|c|}{3 Temmuz 2011 Öncesi Model Tasarımı } & \multicolumn{3}{|c|}{3 Temmuz 2011 Sonrası Model Tasarımı } \\
\hline & Değer & t-İstatistiği & Olasılık & Değer & t-İstatistiği & Olasılık \\
\hline$\alpha \dot{I}$ & 0,16742 & 5,9864 & 0,0000 & 1,426175 & 17,31657 & 0,0000 \\
\hline$\gamma \dot{\mathbf{I}}$ & 0,301351 & 10,75205 & 0,0000 & $-0,598281$ & $-7,967785$ & 0,0000 \\
\hline $\boldsymbol{\beta}_{2}$ & $-12,85143$ & $-7,064903$ & 0,0000 & $-28,7386$ & $-7,646446$ & 0,0000 \\
\hline \multicolumn{7}{|c|}{ PARCH MODELLERİ } \\
\hline \multicolumn{7}{|c|}{$\sigma_{t}^{y}=\alpha_{0}+\sum_{i=1} \alpha_{i}\left(\left|\varepsilon_{t-i}\right|-\delta_{i} \varepsilon_{t-i}\right)^{y}+\sum_{j=1} \beta_{j} \sigma_{t-j}^{y}$} \\
\hline \multirow{2}{*}{ KATSAYI } & \multicolumn{3}{|c|}{3 Temmuz 2011 Öncesi Model Tasarımı } & \multicolumn{3}{|c|}{3 Temmuz 2011 Sonrası Model Tasarım } \\
\hline & Değer & t-İstatistiği & Olasılık & Değer & t-İstatistiği & Olasılık \\
\hline$\alpha \dot{i}$ & 0,165521 & 9,059368 & 0,0000 & $-0,002558$ & $-0,028642$ & 0,9771 \\
\hline$\delta \dot{I}$ & -1 & $-10715,84$ & 0,0000 & $-0,104756$ & $-0,006607$ & 0,9947 \\
\hline$\gamma$ & 0,526636 & 6,071896 & 0,0000 & 1,988503 & 2,600951 & 0,0093 \\
\hline $\boldsymbol{\beta}_{2}$ & $-0,5870$ & $-6,3754$ & 0,0000 & $-0,0789$ & $-0,5114$ & 0,6091 \\
\hline
\end{tabular}

Tablo 23'te 3 Temmuz 2011 öncesi ve sonrası GS getiri serisinde asimetri etkisi ve oynaklık kümelenmesi sonuçları gösterilmiştir. Bununla birlikte, 3 Temmuz öncesi TARCH sonuçlarına göre, ilgili parametrenin $(\theta)$ sıfırdan farklı ve anlamlı olduğunun tespiti nedeniyle asimetrik etki söz konusudur. Ancak, parametre değeri negatif olduğundan modelde kaldıraç etkisi bulunmamaktadır. Olumlu haberlerin oynaklık üzerindeki etkisi daha fazladır. Şike soruşturması sonrası dönemde ise $\% 5$ düzeyinde asimetri ve kaldıraç etkilerinin bulunmadığı görülmektedir. Başka bir ifade ile olumlu ve olumsuz haberlerin oynaklık üzerindeki etkileri farklı değildir.

GS'e ait şike soruşturması öncesi EGARCH modelinde tüm parametrelerin anlamlı olduğu görülmektedir. Ayrıca, $(\gamma)$ parametresi sıfırdan anlamlı bir şekilde farklı olduğundan asimetri etkisi söz konusudur. Fakat parametre değeri pozitif olduğu için kaldıraç etkisi bulunmamaktadır. Başka bir ifadeyle, şike soruşturması öncesinde olumlu şokların GS getiri oynaklığı üzerindeki etkisi daha fazla iken, şike soruşturması sonrasında olumsuz şokların oynaklık üzerindeki etkisinin daha fazla olduğu görülmektedir.

Şike soruşturması öncesi PARCH modeline göre, olumlu ve olumsuz şokların oynaklık üzerindeki etkileri farklı olmasına rağmen olumlu şokların oynaklık üzerindeki etkisinin daha fazla olduğu söylenebilir. Ayrıca, modelde yer alan güç parametresinin pozitif ve anlamlı etkisi, oynaklık kümelenmesinin varlığına işaret etmektedir. Şike soruşturması 
sonrası dönem model çıktıları dikkate alındığında ise, asimetri ve kaldıraç etkilerinin bulunmadığı görülebilmektedir. Güç parametresinin \%5 önem düzeyinde anlamsız çıkması oynaklık kümelenmesinin olmadığını göstermektedir. Ayrıca $\beta_{2}$ değerleri incelendiğinde TARCH ve EGARCH Ulusal 100 getirilerinde meydana gelen artışların BJK getiri oynaklığını ters yönde etkilemektedir.

Tablo 24. TS Getiri Serisi Model Performans Sonuçları

\begin{tabular}{|l|c|c|c|c|c|c|}
\hline \multirow{2}{*}{ DEĞIŞKEN: GETIRITS } & \multicolumn{2}{|c|}{ 3 Temmuz 2011 Öncesi } & \multicolumn{3}{c|}{ 3 Temmuz 2011 Sonrası } \\
\hline MODEL & $\begin{array}{c}\text { Log- } \\
\text { Likelihood }\end{array}$ & AIC & SC & $\begin{array}{c}\text { Log- } \\
\text { Likelihood }\end{array}$ & AIC & SC \\
\hline TARCH (1,1) & 1172,902 & $-4,1306$ & $-4,0845$ & 1161,435 & $-4,09$ & $-4,0439$ \\
\hline EGARCH (1,1) & 1181,156 & $-4,1598$ & $-4,1137$ & 1195,683 & $-4,2112$ & $-4,1652$ \\
\hline PARCH (1,1) & 1185,48 & $-4,1716$ & $-4,1178$ & 1193,802 & $-4,201$ & $-4,1473$ \\
\hline
\end{tabular}

Tablo 24'te TS getiri serisi için oynaklık tahmin modellerine ait model performans sonuçları yer almaktadır. Tabloda yer alan performans ölçütleri incelendiğinde şike soruşturma öncesindeki dönem için PARCH, sonrası için ise EGARCH modelinin daha iyi sonuçlar verebileceği görülmektedir.

Tablo 25. 3 Temmuz 2011 Öncesi ve Sonrası TS Getiri Serisinde Asimetri Etkisi ve Oynaklık Kümelenmesi Sonuçları

\begin{tabular}{|c|c|c|c|c|c|c|}
\hline \multicolumn{7}{|c|}{ TARCH MODELLERİ } \\
\hline \multicolumn{7}{|c|}{$\sigma_{t}^{2}=\alpha_{0}+\sum_{i} \alpha_{t-i}^{2}+\sum_{i} \theta_{t-i} \varepsilon_{t-i}^{2}+\sum^{T} \beta_{j} \sigma_{t-j}^{2}$} \\
\hline \multirow{2}{*}{ KATSAYI } & \multicolumn{3}{|c|}{3 Temmuz 2011 Öncesi Model Tasarımı } & \multicolumn{3}{|c|}{3 Temmuz 2011 Sonrası Model Tasarımı } \\
\hline & Değer & t-İstatistiği & Olasılık & Değer & t-İstatistiği & Olasılık \\
\hline$\alpha_{i}$ & 0,250166 & 5,654442 & 0,0000 & 0,214583 & 6,826592 & 0,0000 \\
\hline$\theta \dot{\mathbf{I}}$ & $-0,240768$ & $-5,397969$ & 0,0000 & $-0,114046$ & $-2,802049$ & 0,0051 \\
\hline $\boldsymbol{\beta}_{2}$ & $-0,005366$ & $-9,825491$ & 0,0000 & $-0,012835$ & $-6,389714$ & 0,0000 \\
\hline \multicolumn{7}{|c|}{ EGARCH MODELLERİ } \\
\hline \multicolumn{7}{|c|}{$L O G\left(G A R C H_{t}\right)=\alpha_{0}+\sum_{i=1} \alpha_{i} \frac{\left|\varepsilon_{t-i}\right|+\gamma_{i} \varepsilon_{t-i}}{\sigma_{t-i}}+\sum_{j=1}$} \\
\hline \multirow{2}{*}{ KATSAYI } & \multicolumn{3}{|c|}{3 Temmuz 2011 Öncesi Model Tasarımı } & \multicolumn{3}{|c|}{3 Temmuz 2011 Sonrası Model Tasarımı } \\
\hline & Değer & t-İstatistiği & Olasılık & Değer & t-İstatistiği & Olasılık \\
\hline $\boldsymbol{\alpha} \dot{i}$ & 0,212007 & 7,68699 & 0,0000 & 0,398174 & 10,83343 & 0,0000 \\
\hline$\gamma \dot{\mathbf{I}}$ & 0,205973 & 8,874889 & 0,0000 & 0,088488 & 3,755033 & 0,0002 \\
\hline $\boldsymbol{\beta}_{2}$ & $-13,34649$ & $-8,810724$ & 0,0000 & $-15,32884$ & $-7,454646$ & 0,0000 \\
\hline \multicolumn{7}{|c|}{ PARCH MODELLERİ } \\
\hline \multicolumn{7}{|c|}{$\sigma_{t}^{y}=\alpha_{0}+\sum_{i=1} \alpha_{i}\left(\left|\varepsilon_{t-i}\right|-\delta_{i} \varepsilon_{t-i}\right)^{y}+\sum_{j=1} \beta_{j} \sigma_{t-j}^{y}$} \\
\hline \multirow{2}{*}{ KATSAYI } & \multicolumn{3}{|c|}{3 Temmuz 2011 Öncesi Model Tasarımı } & \multicolumn{3}{|c|}{3 Temmuz 2011 Sonrasi Model Tasarım } \\
\hline & Değer & t-İstatistiği & Olasılık & Değer & t-İstatistiğgi & Olasılık \\
\hline $\boldsymbol{\alpha} \dot{\mathbf{I}}$ & 0,150329 & 9,843323 & 0,0000 & 0,202178 & 9,151861 & 0,0000 \\
\hline
\end{tabular}


Elitaş, C., Doğan, M., Karahan, Ö. / Journal of Yasar University, 2016, 11/42, 84-101

\begin{tabular}{|l|c|c|c|c|c|c|}
$\boldsymbol{\delta} \dot{\mathbf{I}}$ & $-0,900892$ & $-18,27432$ & 0,0000 & $-0,308406$ & $-4,533754$ & 0,0000 \\
\hline $\boldsymbol{\gamma}$ & 0,411994 & 4,341306 & 0,0000 & 0,802106 & 4,420482 & 0,0000 \\
\hline $\boldsymbol{\beta}_{\mathbf{2}}$ & $-0,758577$ & $-6,195095$ & 0,0000 & $-0,3461$ & $-2,4082$ & 0,0160 \\
\hline
\end{tabular}

Tablo 25'te 3 Temmuz 2011 öncesi ve sonrası TS getiri serisinde asimetri etkisi ve oynaklık kümelenmesi sonuçları gösterilmiştir. Tablo 25 incelendiğinde, şike soruşturması öncesi TS getiri serisine ait TARCH modeli bulguları, hisse senedi getiri oynaklığında asimetri etkisinin var olduğunu ve olumlu haberlerin oynaklığı daha fazla etkilediğini göstermektedir. Şike soruşturması sonrasında da hisse senedi getiri oynaklığında asimetrik etkisinin var olduğu ve olumlu haberlerin oynaklığı etkilediği görülmektedir. TS için düzenlenmiş EGARCH modelinde, şike soruşturması öncesinde asimetrik etkinin olduğu fakat işaretin pozitif olması nedeniyle kaldıraç etkisinin olmadığı görülmüştür. Aynı tespitler şike soruşturması sonrası dönem için de geçerlidir. Ancak, şike soruşturması öncesindeki olumlu şokların TS getiri oynaklığı üzerindeki etkisi şike soruşturması sonrası etkiye göre daha fazladır.

Şike soruşturması öncesi PARCH sonuçlarına göre, olumlu ve olumsuz şokların TS getiri oynaklığı üzerindeki etkileri farklı olup, olumsuz şokların etkisinin olumlu şokların etkisinden daha fazla olmadığı anlaşılmaktadır. Ayrıca, güç parametresinin anlamlı çıkması ve katsayısının pozitif olması oynaklık kümelenmesinin varlığına işarettir. Şike soruşturması sonrası dönemde ise, asimetri etkisinin devam ettiği, ancak olumlu şokların oynaklık üzerindeki etkisinin şike soruşturması öncesi döneme göre çok az arttı̆̆ı görülmektedir. Ayrıca $\beta_{2}$ değerleri incelendiğinde tüm modellerde (TARCH, EGARCH ve PARCH) Ulusal 100 getirilerinde meydana gelen artışlar TS getiri oynaklığını ters yönde etkilemektedir.

\section{Genel Değerlendirme}

Son zamanlarda spor ekonomisinin büyümesiyle birlikte kulüpler gelir kaynaklarını çeşitlendirmek amacıyla hızla şirketleşmeye başlamış ve halka açılmışlardır. Bu kulüplerin başında dört büyük diye nitelendirilen Beşiktaş, Fenerbahçe, Galatasaray ve Trabzonspor kulüpleri gelmektedir. Gelir kaynaklarını çeşitlendirmek amacıyla halka açılan spor kulüplerinde, özellikle taraftarlar tuttukları takımların hisse senetlerini alarak hem gelir elde etmek hem de kulüplerine maddî anlamda yardım etmek istemişlerdir. Ancak 3 Temmuz 2011'de şike soruşturmasının başlatılması borsada işlem gören bu kulüplerin hisse senetleri değerlerinde büyük değişimlere neden olmuştur. Nitekim gelir elde etmek ve kulüplerine yardım etmek amacıyla bu kulüplere ait hisse senetlerini alan yatırımcılar bu değişimlerden önemli derecede etkilenmişlerdir.

Bu araştırmanın amacı; Ulusal 100 (XU100) endeksi ile şike soruşturmasında adı geçen 3 büyük kulübün (BeşiktaşBJK, Fenerbahçe-FB, Trabzonspor-TS) ve soruşturma kapsamı dışındaki Galatasaray'ın (GS) hisse senetleri üzerinde meydana getirdiği davranış değişikliklerini tespit edilmiştir. Başka bir ifade ile bu araştırmada şike iddiası ile ilgili haberlerin getiri değişkenliğinde yarattığı olası etkiler tespit edilecektir. Araştırmada futbol kulüplerine ait günlük getiri verilerinin şike soruşturmasının başladığ tarih olan 03.07.2011 tarihi öncesi ve sonrası dönemler için ayrı ayrı analizler yapılmıştır.

Analiz sonuçları incelendiğinde şike soruşturması sonrası dönemde, şike soruşturması öncesi döneme göre FB getiri serisinin hem kendi şoklarından hem de XU100 endeksindeki şoklardan daha uzun süre etkilendiği söylenebilir. GS getiri serisinin kendi değerlerinde yaşanan şoklardan 1 dönem gecikmeli olarak en yüksek düzeyde doğru orantılı olarak etkilendiği ve bu etkinin takip eden ikinci gün içerisinde ciddi oranda azaldığı ve 3. günde ise ortadan kalktığ görülmüştür. Serinin XU100 getiri değişimlerindeki şoklardan etkilenme davranışı, nispeten az ve ikinci günün sonunda ortadan kalkmaktadır. Bununla birlikte, şike soruşturması öncesinde XU100 getirilerindeki \%1'lik değişim en çok sırasıyla BJK, FB, TS ve GS'yi etkilemektedir. Bu etki şike sonrası dönemde ise GS, BJK, TS ve FB olarak sıralanmaktadır. Şike soruşturmasında ismi geçen Beşiktaş, Fenerbahçe, Trabzonspor'un şike sonrası dönemde ulusal 100 endeksi ile etkileşimi azalmakta, daha çok kendi şoklarından etkilenmişlerdir. Özellikle şike soruşturması sonrası dönemde, şike soruşturması öncesi döneme göre GS getiri serisi ile XU100 getiri endeksinin etkileşimi oldukça yükselmektedir.

Şike soruşturması sonrası dönemde FB getiri serisinde meydana gelen olumlu şokların olumsuz şoklara göre oynaklık üzerindeki etkisinin daha fazladır. Ancak, olumlu haberlerin oynaklık üzerindeki etkisinin şike soruşturması öncesi döneme göre bariz bir şekilde azaldığı söylenebilir. Şike soruşturması öncesindeki olumlu şokların TS getiri oynaklığ üzerindeki etkisi şike soruşturması sonrası etkiye göre daha fazladır. 


\section{KAYNAKÇA}

Aksar,

$\mathrm{T}$.

2011.

"Şike

Ekonomisi",

$8 \quad$ Temmuz

2013 ,

http://www.futbolekonomi.com/index.php?option=com_content\&view=article\&id=1683:ikefenerbahce\&catid $=35:$ tugrulaksar\&Itemid $=57$.

Akyıldız, M. 2007. "Sosyal Sorumluluk ve Ahlaki Yaklaşımlar Çerçevesinde Pazarlamanın Sürdürülebilir Gelişmedeki Rolü”, Dokuz Eylül Üniversitesi Sosyal Bilimler Enstitüsü Dergisi, Cilt: 9, Sayı: 1, s. 18-43.

Aydın, İ. 2012. "Yönetsel, Mesleki ve Örgütsel Etik", Ankara, Pegem Akademi.

Donay, S. 2011. "Sporda Şiddet Ve Düzensizliğin Önlenmesi Ve Şike Ve Teşvik Primi”, İstanbul, Beta Yayınevi.

Gökten, S. ve Karatepe, S. 2015. "Effects of Match-fixing Related Publications on Football Clubs' Stock Prices: An Example from Turkey", Muhasebe ve Finansman Dergisi, Say1: 68, s. 169-184.

Kaypak, Ș. 2010. "Kentsel Dönüşüm Faaliyetlerine Etik ve Sosyal Sorumluluk Temelli Bir Yaklaşım”, Niğde Üniversitesi IIBF Dergisi, Cilt: 3, Say1: 2, s. 84-105.

Kisakürek, M. M. ve Alpan, N. 2010. "Muhasebe Meslek Etiği ve Sivas İlinde Bir Uygulama", Muhasebe ve Finansman Dergisi, Say1: 47, s. 213-228.

Mahmutoğlu, A. 2009. “Etik ve Ahlak: Benzerlikler, Farklılıklar ve İlişkiler”, Türk İdare Dergisi, Sayı: 463-464, s. 225249.

Özen, M. ve Yılmaz, S. 2012. "Şike ve Teşvik Primi Suçları", Ankara Barosu Dergisi, Sayı: 2, s. 19-41.

Seydi, A. 2013.” Sporda Şike ve Teşvik Primi”, http://www.msxlabs.org/forum/turkiyede-futbol/9035-sporda-sike-vetesvik-primi.html

Şen, E. ve Özdemir, B. 2012. "Şike”, 08.09.2013, http://www.hukukihaber.net/sike-makale,2593.html.

Şenol, T. (2013). Spor Hukuku ve Spor Etiği Işs̆ğında Fair Play. Ankara Barosu Spor Hukuku Kurulu “Av. İsmail İnan” Armağanı, s. 705-715.

Tokgöz, N. (2013). İş Etiği. Eskişehir: Anadolu Üniversitesi.

Tuncel, S. D. ve Büyüköztürk, Ş. 2009. "Antrenörlerin Mesleki Etik İlkeleri Nelerdir? Nasıl Ölçülür? Ölçek Geliştirme: Ölçeğin Geçerlik ve Güvenirliği”, Spormetre Beden Eğitimi ve Spor Bilimleri Dergisi, Cilt: 7, Sayı: 4, s. 159168.

Tuzcuoğlu, E. 2011. "Şike ve Teşvikte TFF Disiplin Yargılaması”, İstanbul Barosu Dergisi, Cilt: 85, Sayı: 5, s. 108119.

Yılmaz, N. 2009. "Yerel Basının Etik Sorunları”, İstanbul Üniversitesi İletişsim Fakültesi Dergisi, Sayı: 36, s. 131-143. 